\title{
Molecular biology of autoinflammatory diseases
}

\author{
Junya Masumoto ${ }^{*}$, Wei Zhou, Shinnosuke Morikawa, Sho Hosokawa, Haruka Taguchi, Toshihiro Yamamoto, \\ Mie Kurata and Naoe Kaneko
}

\begin{abstract}
The long battle between humans and various physical, chemical, and biological insults that cause cell injury (e.g., products of tissue damage, metabolites, and/or infections) have led to the evolution of various adaptive responses. These responses are triggered by recognition of damage-associated molecular patterns (DAMPs) and/or pathogen-associated molecular patterns (PAMPs), usually by cells of the innate immune system. DAMPs and PAMPs are recognized by pattern recognition receptors (PRRs) expressed by innate immune cells; this recognition triggers inflammation. Autoinflammatory diseases are strongly associated with dysregulation of PRR interactomes, which include inflammasomes, NF-kB-activating signalosomes, type I interferon-inducing signalosomes, and immuno-proteasome; disruptions of regulation of these interactomes leads to inflammasomopathies, relopathies, interferonopathies, and proteasome-associated autoinflammatory syndromes, respectively. In this review, we discuss the currently accepted molecular mechanisms underlying several autoinflammatory diseases.
\end{abstract}

Keywords: Interleukin-1, NF-KB, Type I interferon, Autoinflammatory diseases

\section{Background}

The human body has evolved various adaptive responses that protect against cell and tissue damage caused by physical, chemical, and biological factors. Such factors include molecules released by damaged tissues, metabolites, and/or infection (e.g., by bacteria, viruses, and parasites) [1-4]. Inflammation, an adaptive response to cell injury, generates damage-associated molecular patterns (DAMPs) and/or pathogen-associated molecular patterns (PAMPs), which are then recognized by pattern recognition receptors (PRRs) expressed mainly by innate immune cells [5]. PRRs include Toll-like receptors (TLRs), Nod-like receptors (NLRs), C-type lectin receptors (CLRs), and RIG-I-like receptors (RLRs) that recognize DAMPs and PAMPs to initiate immune responses. These receptors are also called innate immune receptors [6] (Fig. 1).

Autoinflammatory diseases are strongly associated with dysregulation of these PRR-containing interactomes, which

\footnotetext{
*Correspondence: masumoto@m.ehime-u.ac.jp

Department of Pathology, Ehime University Graduate School of Medicine and Proteo-Science Center, Shitsukawa 454, Toon, Ehime 791-0295, Japan
}

include inflammasomes, nuclear factor (NF)-kB-activating signalosomes, type I interferon-inducing signalosomes, and immuno-proteasomes; dysfunction of these interactomes results in inflammasomopathies, relopathies, interferonopathies, and proteasome-associated autoinflammatory syndromes (PRAAS), respectively [7-11]. This explains the pathogenesis of autoinflammatory diseases involving recurrent inflammatory flare-ups in the absence of autoantibodies or antigen-specific $\mathrm{T}$ lymphocytes [12]. Knowledge of the molecular mechanism(s) underlying the functions of these innate immune receptors is useful for the treatment and management of individuals with autoinflammatory diseases (Fig. 1).

\section{Interleukin-1 $\beta$-mediated autoinflammatory diseases (inflammasomopathies)}

When NOD-like receptors harboring a PYRIN domain (PYD) (e.g., NLRP1, NLRP2, NLRP3, NLRP6, NLRP9, and NLRP12) and other pyrin domain-containing PRRs (e.g., pyrin, AIM2, and IFI-16) sense DAMPs, PAMPs, or intracellular microenvironmental changes (e.g., potassium efflux), they interact with an adaptor protein

(c) The Author(s). 2021 Open Access This article is licensed under a Creative Commons Attribution 4.0 International License, which permits use, sharing, adaptation, distribution and reproduction in any medium or format, as long as you give appropriate credit to the original author(s) and the source, provide a link to the Creative Commons licence, and indicate if changes were made. The images or other third party material in this article are included in the article's Creative Commons licence, unless indicated otherwise in a credit line to the material. If material is not included in the article's Creative Commons licence and your intended use is not permitted by statutory regulation or exceeds the permitted use, you will need to obtain permission directly from the copyright holder. To view a copy of this licence, visit http://creativecommons.org/licenses/by/4.0/. 


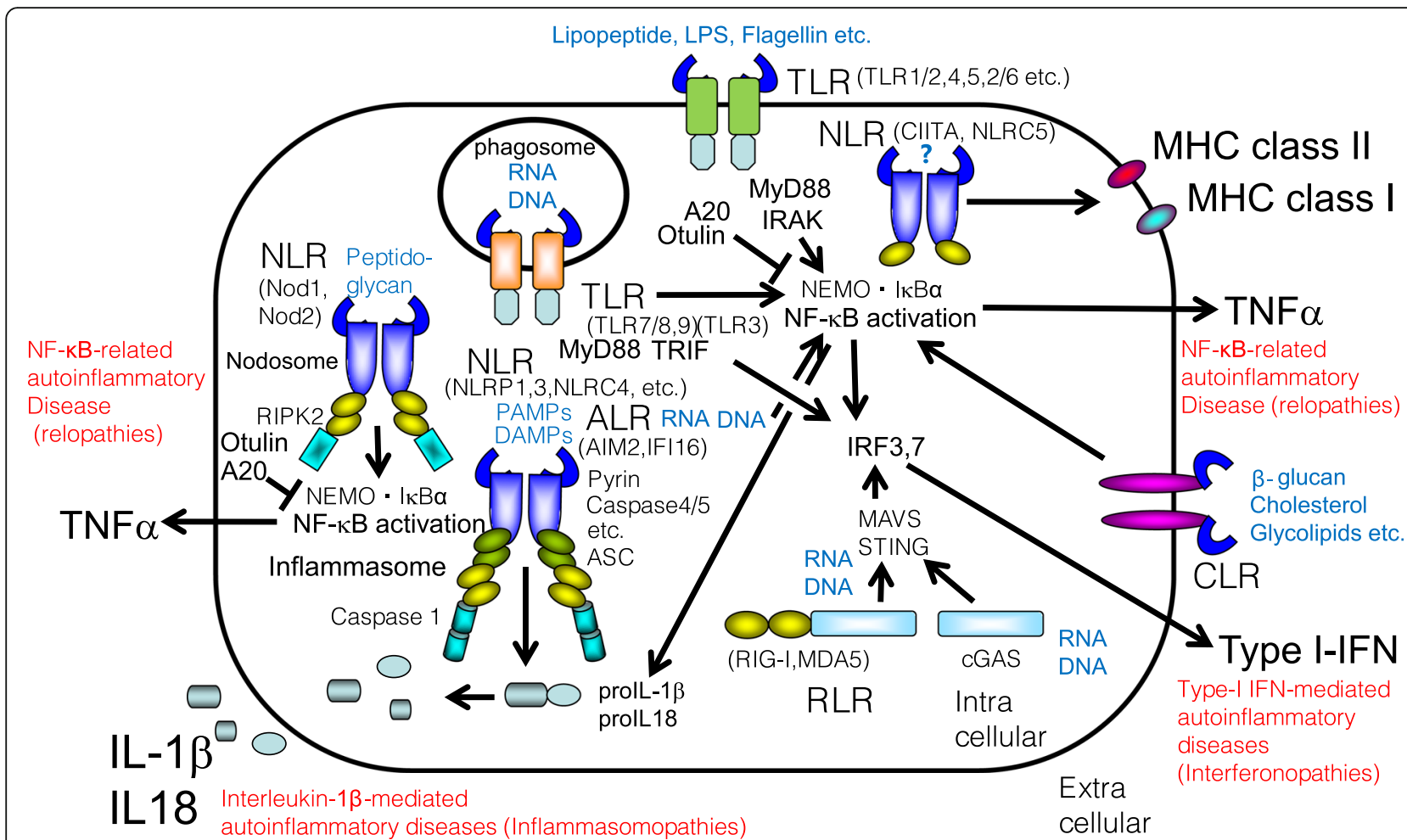

Fig. 1 Pattern-recognition receptors in innate immune cells. PRRs include Toll-like receptors (TLRs), Nod-like receptors (NLRs), and RIG-I-like receptors (RLRs) that recognize various damage-associated molecular patterns (DAMPs) and pathogen-associated molecular patterns (PAMPs) to initiate immune responses. These receptors are also called innate immune receptors. Gain-of-function mutations of the innate immune receptors or loss-of-function mutations of their inhibitors are related to autoinflammatory diseases. Red characters indicate DAMPs and PAMPs. Red characters indicate classified autoinflammatory diseases

apoptosis-associated speck-like protein containing a caspase-recruitment domain (ASC) via PYD, and procaspase-1 via a caspase-recruitment domain (CARD). This interaction activates caspase-1, a process accompanied by pyroptotic cell death [13-29]. NOD-like receptors carrying a CARD domain or CARD including proteins alternatively interact with caspase- 1 via CARD with ASC and pro-caspase-1 such as NLRP1, NLRC4, CARD8, and caspase-11 [30-32]. The resulting complexes act as a sensor of cell injury; this sensor is referred to as the inflammasome, an interleukin (IL)-1 $\beta$ and IL-18-processing platform that plays a crucial role in the maturation and secretion of these cytokines from cells. The process is accompanied by a type of cell death, named pyroptosis, which is triggered by cleavage of gasdermin D (GSDMD) [33, 34] (Fig. 2). Below, we discuss specific inflammasomopathies.

\section{Cryopyrin-associated periodic syndrome}

Cryopyrin is the same protein as NLRP3 which was named by the nomenclature committee. Gain-offunction mutations in NLRP3 lead to cryopyrinassociated periodic syndrome (CAPS), a spectrum of diseases that includes familial cold autoinflammatory syndrome (FCAS, formerly termed familial cold urticaria (FCU)), Muckle-Wells syndrome (MWS), and neonatalonset multisystem inflammatory disease (NOMID; also called chronic infantile neurologic cutaneous and articular syndrome (CINCA)). Currently, 248 variants of the CIAS1 gene have been reported by "INFEVERS" (https:// infevers.umai-montpellier.fr/web/search.php?n=4) [35]. The NLRP3 mutations in CAPS result in constitutive activation of the NLRP3 inflammasome (i.e., the threshold for stimulation is extremely low). Activation of the inflammasome leads to excess pyroptosis of cells expressing components of the NLRP3 inflammasome; these cells secrete excessive amounts of activated IL- $1 \beta$ upon autoinflammatory attack [36-41] (Fig. 2). Corresponding common diseases caused by the similar signaling are shown in Table 1.

\section{NLRP1-associated autoinflammation with arthritis and dyskeratosis}

The NLRP1 inflammasome was the first "inflammasome" to be identified [14]. NLRP1 interacts with ASC through its PYD domain. ASC then interacts with procaspase-1 via its CARD domain, resulting in activation of IL-1 $\beta$ secretion; also, NLRP1 interacts with caspase-1 


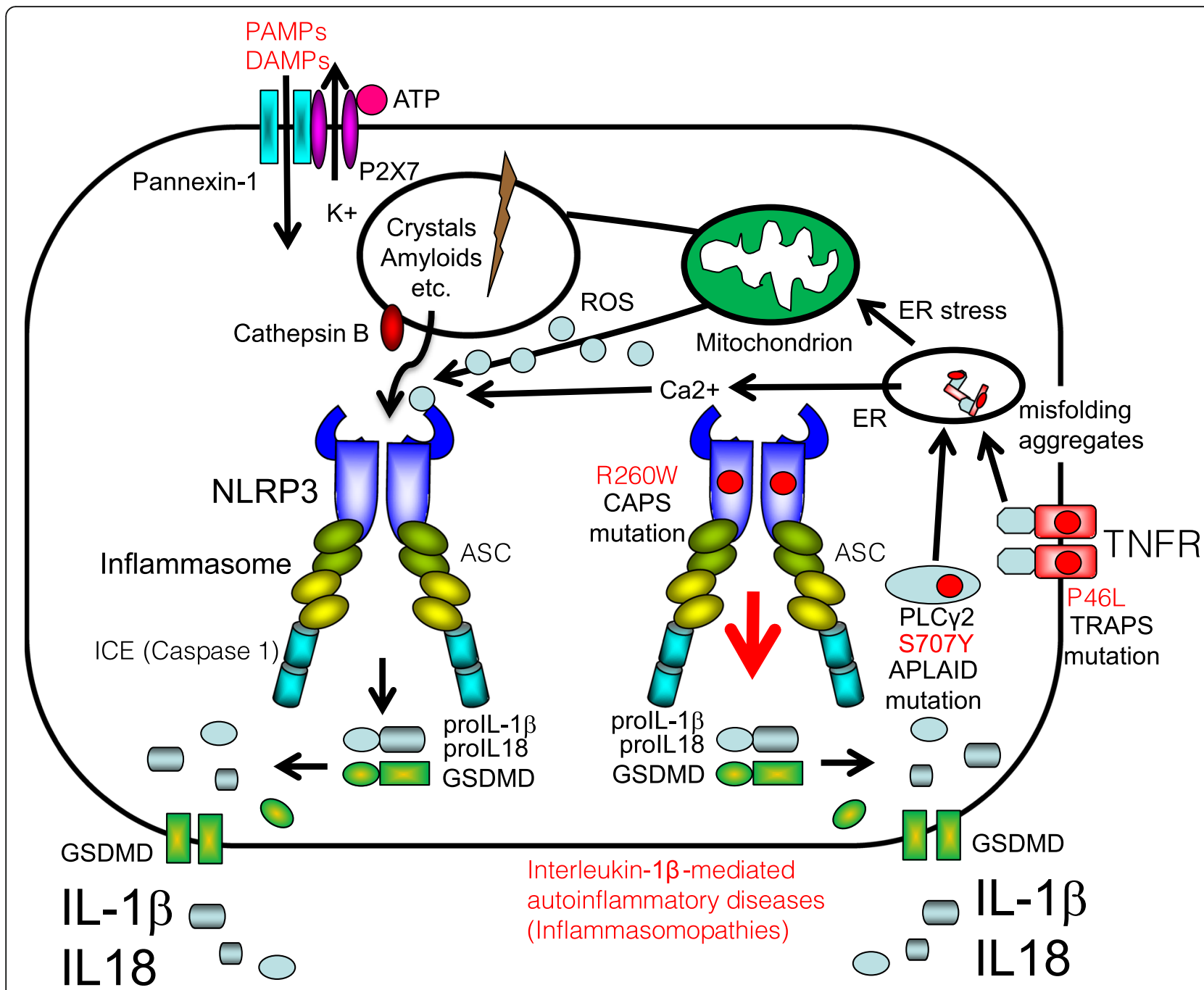

Fig. 2 Cryopyrin-associated periodic fever syndrome (CAPS), TNF receptor-associated periodic syndrome (TRAPS), and autoinflammation and phospholipase CY2 (PLCY2)-associated antibody deficiency and immune dysregulation (APLAID) are related to NLRP3 inflammasome. Gain-of-function mutations of NLRP3 (e.g., R260W) leads to prolonged activation of NLRP3 inflammasome. Autoinflammatory syndrome caused by the gain of function of NLRP1, NLRP12, or other NLRP mutations is thought to be basically caused by the same mechanisms. Mutated TNFRSF1A (TNFR) in patients with TRAPS is misfolded and accumulated in the endoplasmic reticulum (ER), causing ER stress and increased generation of mitochondrial reactive oxygen species (ROS) that activates the NLRP3 inflammasome. PLCY2 mutation in patients with APLAID (e.g., S707Y) leads to calcium influx from the ER and increased cytoplasmic Ca2+ levels promote activation of NLRP3 inflammasome

through its CARD domain to activate IL-1 $\beta$ secretion [96]. Currently, several mutations (A54T, A59P, A66V, M77T, R726W, T755N, F787_R843del, and P1214R) in the gene encoding NLRP1 have been identified (https:// infevers.umai-montpellier.fr/web/search.php?n=31). Patients harboring these mutations exhibit dyskeratosis, oligo/polyarthritis, and recurrent fever, along with immunological dysfunction and vitamin A deficiency [9799]. The mutations may trigger proteasome-dependent functional degradation of NLRP1, and degraded CARDFIIND-containing-NLRP1 fragments act as a scaffold like ASC for inflammasome activation [100] (Fig. 2).
Corresponding common diseases caused by the similar signaling are shown in Table 1.

\section{NLRP12 autoinflammatory syndrome}

NLRP12 inhibits the activation of NF- $\mathrm{BB}$. Mutations in NLRP12 are found in patients with hereditary periodic fever syndrome, the clinical signs of which are consistent with a diagnosis of CAPS [101]. Currently, 79 variants of the gene encoding NLRP12 have been reported (https:// infevers.umai-montpellier.fr/web/search.php?n=9). Since some patients with gain-of-function mutations in NLRP12 exhibit symptoms similar to those of CAPS, the 
Table 1 The corresponding diseases caused by the similar signaling of autoinflammatory diseases

\begin{tabular}{|c|c|c|c|}
\hline $\begin{array}{l}\text { Type of autoinflammatory } \\
\text { diseases }\end{array}$ & $\begin{array}{l}\text { Responding } \\
\text { proteins }\end{array}$ & Functions & Corresponding diseases with the similar signaling \\
\hline \multicolumn{4}{|c|}{ Inflammasomopathies } \\
\hline \multirow[t]{14}{*}{ CAPS } & \multirow[t]{14}{*}{ Cryopyrin/NLRP3 } & \multirow{14}{*}{$\begin{array}{l}\text { PRR for ROS, } K^{+} \text {efflux, cathepsin } \\
\text { B detection }\end{array}$} & Metabolic syndrome: \\
\hline & & & Gout [42] \\
\hline & & & Atherosclerosis [43] \\
\hline & & & Type 2 diabetes [44] \\
\hline & & & Neurodegenerative disease: \\
\hline & & & Alzheimer's disease $[45,46]$ \\
\hline & & & Parkinson's disease [47] \\
\hline & & & Amyotrophic lateral sclerosis [48] \\
\hline & & & Multiple sclerosis [49] \\
\hline & & & Infections and aberrant inflammatory responses: \\
\hline & & & Septic shock syndrome $[50,51]$ \\
\hline & & & Ischemic diseases: \\
\hline & & & Myocardial infarction [52] \\
\hline & & & Stroke [53] \\
\hline \multirow[t]{6}{*}{ NAIAD } & \multirow[t]{6}{*}{ NLRP1 } & \multirow{6}{*}{$\begin{array}{l}\text { PRR against Anthrax toxin } \\
\text { detection }\end{array}$} & Infections and aberrant inflammatory responses: \\
\hline & & & Anthrax lethal toxin [54] \\
\hline & & & Neurodegenerative disease: \\
\hline & & & Alzheimer's disease [46] \\
\hline & & & Ischemic diseases: \\
\hline & & & Stroke [53] \\
\hline \multirow[t]{6}{*}{ NLRP12-AD } & \multirow[t]{6}{*}{ NLRP12 } & \multirow[t]{3}{*}{ PRR for Yersinia pestis detection } & Infections and aberrant inflammatory responses: \\
\hline & & & Yersinia pestis [55] \\
\hline & & & Plasmodium chabaudi [56] \\
\hline & & \multirow[t]{3}{*}{ NF-kB inhibition } & Regulation of inflammation: \\
\hline & & & Salmonella typhimurium [57] \\
\hline & & & Brucella abortus [58] \\
\hline \multirow[t]{2}{*}{ TRAPS } & \multirow[t]{2}{*}{ TNFRSF1A } & \multirow[t]{2}{*}{ TNF receptor } & Infections and aberrant inflammatory responses: \\
\hline & & & Tumor necrosis factor [59] \\
\hline \multirow[t]{8}{*}{ APLAID } & \multirow[t]{8}{*}{ PLCY2 } & \multirow[t]{8}{*}{ Cleavage PIP to DAG } & Immunodeficiency: \\
\hline & & & Common variable immunodeficiency [60] \\
\hline & & & $\begin{array}{l}\text { PLCY2-associated antibody deficiency and immune dysregulation } \\
\text { syndrome (PLAID) [60] }\end{array}$ \\
\hline & & & Familial cold autoinflammatory syndrome 3 [60] \\
\hline & & & Neurodegenerative disease: \\
\hline & & & Alzheimer's disease $[61,62]$ \\
\hline & & & Lewy body dementia [62] \\
\hline & & & Frontotemporal dementia [62] \\
\hline \multirow[t]{2}{*}{ FMF } & \multirow[t]{2}{*}{ Pyrin } & \multirow[t]{2}{*}{ Virulence sensor } & Infections and aberrant inflammatory responses: \\
\hline & & & Yersinia pestis infection [63] \\
\hline \multirow[t]{2}{*}{ PFIT } & \multirow[t]{2}{*}{ WDR1 } & \multirow{2}{*}{$\begin{array}{l}\text { Actin assembly, leukocyte } \\
\text { migration }\end{array}$} & Infections and aberrant inflammatory responses: \\
\hline & & & Listeria monocytogenes dissemination [64] \\
\hline \multirow[t]{2}{*}{ PAAND } & \multirow[t]{2}{*}{ Pyrin } & Virulence sensor & Infections and aberrant inflammatory responses: \\
\hline & & & Yersinia pestis infection [63] \\
\hline
\end{tabular}


Table 1 The corresponding diseases caused by the similar signaling of autoinflammatory diseases (Continued)

\begin{tabular}{lll}
\hline $\begin{array}{l}\text { Type of autoinflammatory } \\
\text { diseases }\end{array}$ & $\begin{array}{l}\text { Responding } \\
\text { proteins }\end{array}$ & Functions \\
\hline PAPA syndrome & PSTPIP1/CD2BP1 & Pyrin regulation \\
MKD & MVK & Lipid metabolism \\
$\begin{array}{l}\text { NLRC4 } \\
\text { inflammasomopathies }\end{array}$ & PLRC4 & PRR for flagellin detection \\
Relopathies & NOD2 & PRR for MDP \\
BS/EOS & A20/TNFAIP3A & $\begin{array}{l}\text { Deubiquitinating for NF-KB } \\
\text { regulation }\end{array}$ \\
HA20 & & \\
& & \\
IAALUCD & LUBAC & $\begin{array}{l}\text { Ubiquitinating for NF-KB } \\
\text { regulation }\end{array}$ \\
& HOIL-1/ RBCK1 & \\
HOIP/RNF31 & \\
SHARPIN & Deubiquitinating for NF-KB \\
& OTULIN & regulation \\
& &
\end{tabular}

\section{IL-1 receptor-related autoinflammatory diseases:}
DIRA
IL1RN
IL-1 receptor inhibitor

\section{Interferonopathies}

AGS

RNASEH2 RNase activity against viral RNA

SAVI

COPA syndrome

PRAAS/NNS/CANDLE
RNASEH2

SAMHD1

ADAR1

$\mathrm{MDA} 5 / \mathrm{FIH1}$

dNTPase activity against viral RNA/DNA

Viral RNA processing

PRR for viral RNA detection

STING/TMEM173 PRR for viral DNA/RNA detection

aCOP

PSMB3,4,8,9 to $E R$
Corresponding diseases with the similar signaling

Immunodeficiency:

Common variable immunodeficiency [65]

Metabolic syndrome:

Atherosclerosis [66]

Infections and aberrant inflammatory responses:

Pseudomonas aeruginosa infection [67]

Macrophage activation syndrome (MAS) [68]

Infections and aberrant inflammatory responses:

Mycobacterium tuberculosis infection [69]

Infections and aberrant inflammatory responses:

Systemic lupus erythematosus (SLE) [70]

Rheumatoid arthritis [71]

Infections and aberrant inflammatory responses:

Salmonella enterica infection [72]

Legionella pneumophila infection [72]

Shigella flexneri infection [72]

Infections and aberrant inflammatory responses:

Salmonella Typhimurium infection [73]

Infections and aberrant inflammatory responses:

Inflammasomopathies [74]

Infections and aberrant inflammatory responses:

SLE and other autoimmune diseases $[75,76]$

Cervical cancer via human papilloma virus [77]

Epstein-Barr virus infection [78]

Human immunodeficiency virus infection [79]

Hepatitis B virus infection [80]

Marburg and Ebola virus [81]

Paramyxovirus infection [82]

Picornavirus infection [83]

Infections and aberrant inflammatory responses:

SLE and other autoimmune diseases [76]

ANCA-associated vasculitis [84]

Herpes simplex virus infection [85]

Transport vesicles between Golgi Infections and aberrant inflammatory responses:

Interstitial lung disease [86]

Capillaritis [87]

Infections and aberrant inflammatory responses:

SLE and other autoimmune disease [87, 88]

Cytomegalovirus infection [89]

Hepatitis B virus infection [90]

Influenza virus infection [91] 
Table 1 The corresponding diseases caused by the similar signaling of autoinflammatory diseases (Continued)

\begin{tabular}{|c|c|c|c|}
\hline $\begin{array}{l}\text { Type of autoinflammatory } \\
\text { diseases }\end{array}$ & $\begin{array}{l}\text { Responding } \\
\text { proteins }\end{array}$ & Functions & Corresponding diseases with the similar signaling \\
\hline & POMP & Proteasome chaperone & Infections and aberrant inflammatory responses: \\
\hline & & & Psoriasis [92] \\
\hline & & & Human papilloma virus infection [93] \\
\hline \multirow[t]{7}{*}{ SMS } & $\mathrm{MDA} 5 / \mathrm{IFIH1}$ & PRR for viral RNA detection & Infections and aberrant inflammatory responses: \\
\hline & & & SLE and other autoimmune diseases $[75,76,94]$ \\
\hline & & & Paramyxovirus infection [82] \\
\hline & & & Picornavirus infection [83] \\
\hline & RIG-I & PRR for viral RNA detection & Infections and aberrant inflammatory responses: \\
\hline & & & SLE and other autoimmune diseases [95] \\
\hline & & & Paramyxovirus infection [83] \\
\hline
\end{tabular}

disease was named FCAS2 [102] and patients with NALP12 periodic fever syndrome respond to canakinumab (an anti-human IL-1 $\beta$ monoclonal antibody) and/or etanercept (a tumor necrosis factor (TNF) receptor-IgG heavy chain chimeric protein that acts as a bivalent antagonist of TNF activity) [102], the pathogenesis of NLRP12 autoinflammatory syndrome (NLRP12-AD) may explain the gain of function of the NLRP12 inflammasome by a similar mechanism of the NLRP3 inflammasome (Fig. 2). Corresponding common diseases caused by the similar signaling are shown in Table 1 .

\section{TNF receptor-associated periodic fever syndrome}

The causative gene product of TNF receptor-associated periodic fever syndrome (TRAPS) is TNF receptor superfamily member 1A (TNFRSF1A) [12]. So far, 180 variations of the TNFRSF1A gene have been reported (https://infevers.umai-montpellier.fr/web/search.php?n= $2)$. The cysteine-to-cysteine disulfide bonds in the extracellular domain of TNFRSF1A for ER stress are thought to be important for disease pathogenesis. More than one-third of patients with TRAPS harbor the R92Q and P46L mutations [103]. In TRAPS, misfolding of mutated TNFRSF1A leads to accumulation of the protein in the endoplasmic reticulum (ER), which causes ER stress and increased generation of mitochondrial reactive oxygen species; this in turn activates inflammasomes [104, 105] (Fig. 2). Corresponding common diseases caused by the similar signaling are shown in Table 1.

\section{Autoinflammation and phospholipase $\mathrm{C} \gamma 2$-associated antibody deficiency and immune dysregulation} Autoinflammation and phospholipase $\mathrm{C}_{2} 2$ (PLC $\mathrm{P} 2$ )-associated antibody deficiency and immune dysregulation (APLAID) responds to PLC 2 which encodes for a constitutively repressed phospholipase. The S707Y PLC 2 mutation disrupts the autoinhibition of PLC $\gamma 2$, thereby increasing $\mathrm{PLC} \gamma 2$ activity and calcium influx from the
ER in the leukocytes of patients with APLAID [106, 107]. Increased cytoplasmic $\mathrm{Ca} 2+$ levels promote the assembly of the NLRP3 inflammasome [108] (Fig. 2). Corresponding common diseases caused by the similar signaling are shown in Table 1.

\section{Familial Mediterranean fever}

The causative gene of familial Mediterranean fever (FMF), $M E F V$, encodes pyrin (also named marenostrin) [109, 110]. Currently, 389 variants of $M E F V$ have been reported (https://infevers.umai-montpellier.fr/web/ search.php?n=1). FMF was reported to be autosomal recessive; mutations in pyrin are thought to result in loss of its ability to inhibit inflammasomes. Nowadays, pyrin assembles with ASC and pro-caspase-1 to form the pyrin inflammasome, as well as the NLRP3 inflammasome [111]. Usually, pyrin is phosphorylated by serine/ threonine-protein kinases PKN1 and PKN2, and inhibited by 14-3-3 proteins. When virulence factors expressed or secreted by bacteria and/or viruses inhibit RhoA GTPase, the pyrin inflammasome triggers activation and secretion of IL-1 $\beta$ [112] (Fig. 3). Yersinia pestislike bacteria have a YopM protein which interacts with pyrin to inhibit inflammatory responses for avoiding further anti-bacterial responses [113]. In patients with FMF, pyrin harboring mutant human B30.2 domains defect such kind of ability, thereby preventing binding to ASC; this makes prolonged inflammasome activation and IL-1 $\beta$ secretion [114] (Fig. 3). Corresponding common diseases caused by the similar signaling are shown in Table 1.

Periodic fever immunodeficiency and thrombocytopenia The causative gene product of periodic fever immunodeficiency and thrombocytopenia (PFIT) is WDR1 [115, 116], which interacts with cofilin to promote cleavage and depolymerization of F-actin $[117,118]$. The L293F mutation in WDR1 disrupts intramolecular hydrophobic 


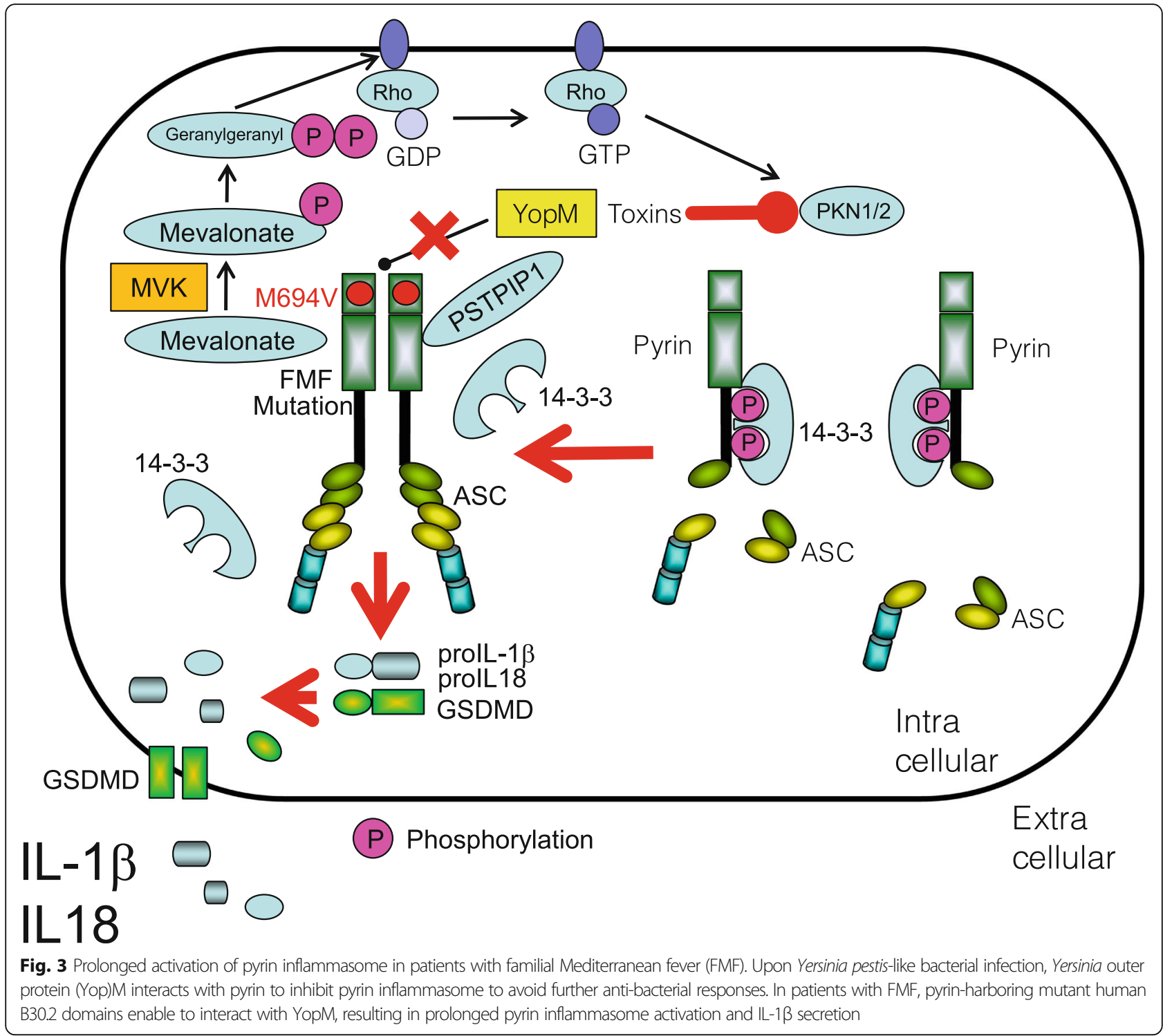

interactions, which are important for maintaining actin protein structure. This disruption leads to actin accumulation and aggregates with pyrin resulting in pyrin activation and release of IL-18 [119] (Fig. 4). Corresponding common diseases caused by the similar signaling are shown in Table 1.

\section{Pyrin-associated autoinflammation with neutrophilic dermatosis}

The $M E F V$ mutations in patients with pyrin-associated autoinflammation with neutrophilic dermatosis (PAAND) harbor S242R and E244K mutations in pyrin; these mutations are located in the 14-3-3 binding motif, which interferes with binding of pyrin to 14-3-3, thereby allowing assembly of the pyrin inflammasome and excessive release of IL-1 $\beta$ [120-123] (Fig. 5). Corresponding common diseases caused by the similar signaling are shown in Table 1 .

\section{Pyogenic arthritis, pyoderma gangrenosum, and acne syndrome}

The causative gene product of pyogenic arthritis, pyoderma gangrenosum, and acne (PAPA) syndrome is proline-serinethreonine phosphatase-interacting protein 1 (PSTPIP1) (also called CD2-binding protein 1 (CD2BP1)) [124, 125]. Currently, 66 variants of the PSTPIP1 gene have been reported (https://infevers.umai-montpellier.fr/web/search.php?n=5). In patients with PAPA syndrome, mutations in PSTPIP1 result in hyperphosphorylation of PSTPIP1, which strengthens its interaction with pyrin via the B-box domain to activate the pyrin inflammasome. This leads to increased secretion of IL- 


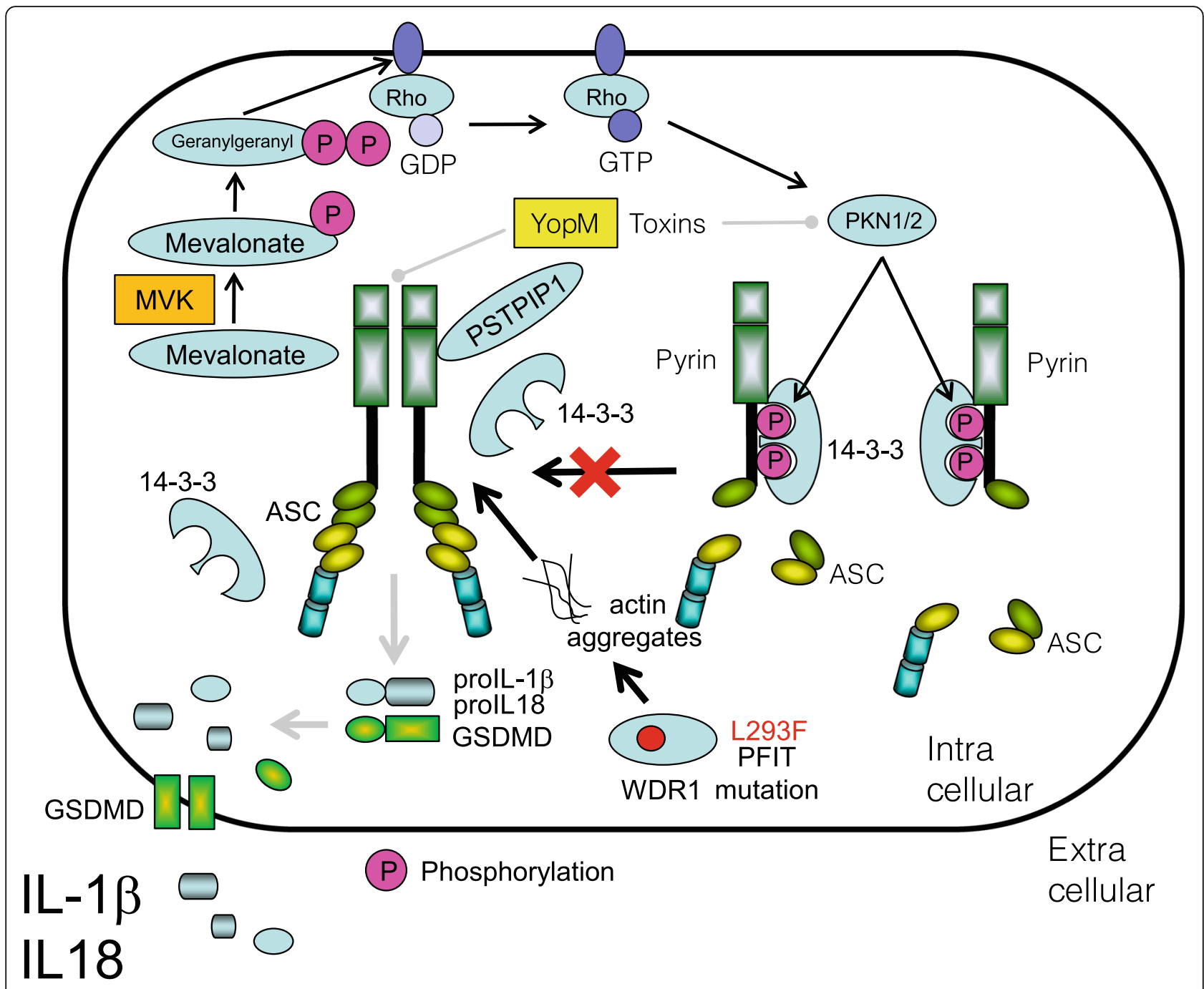

Fig. 4 Activation of pyrin inflammasome is inhibited by phosphorylation by PKN1/2. Upon bacterial infection, bacterial toxin can inhibit PKN1/2 activity, resulting in pyrin inflammasome activation. The L293F mutation in WDR1 leads to actin accumulation and aggregates with pyrin, resulting in pyrin activation

$1 \beta$ [125] (Fig. 6). Corresponding common diseases caused by the similar signaling are shown in Table 1.

\section{Mevalonate kinase deficiency/hyper-IgD syndrome}

The causative gene product of mevalonate kinase deficiency/hyper-IgD syndrome (MKD) (also known as hyper-IgD syndrome (HIDS)) is mevalonate kinase (MVK) [126]. Currently, 264 variants of this gene have been reported (https://infevers.umai-montpellier.fr/web/ search.php?n=3). Geranylgeranyl pyrophosphate, the substrate of geranylgeranylation, is a product of the mevalonate pathway. Deficiency of MVK leads to depletion of geranylgeranyl pyrophosphate, resulting in the inactivation of RhoA [127, 128]. Since the inactivation of RhoA activates the pyrin inflammasome, MKD leads to an inflammasomopathy. Indeed, canakinumab, an anti-
IL-1 $\beta$ monoclonal antibody, is an effective treatment for MKD, suggesting that IL- $1 \beta$ is a common mediator of these diseases [129] (Fig. 7). Corresponding common diseases caused by the similar signaling are shown in Table 1.

\section{NLRC4 inflammasomopathies}

Gain-of-function mutations in NLRC4 result in earlyonset recurrent fever and macrophage activation syndrome (MAS), neonatal-onset enterocolitis with periodic fever, fatal or near-fatal episodes of autoinflammation, or symptoms resembling those of FCAS $[68,130,131]$. So far, more than 31 genetic variants of NLRC4 have been reported (https://infevers.umai-montpellier.fr/web/ search.php? $\mathrm{n}=25$ ). The NLRC4 inflammasome activates caspase-1 either with or without an adaptor ASC, which 


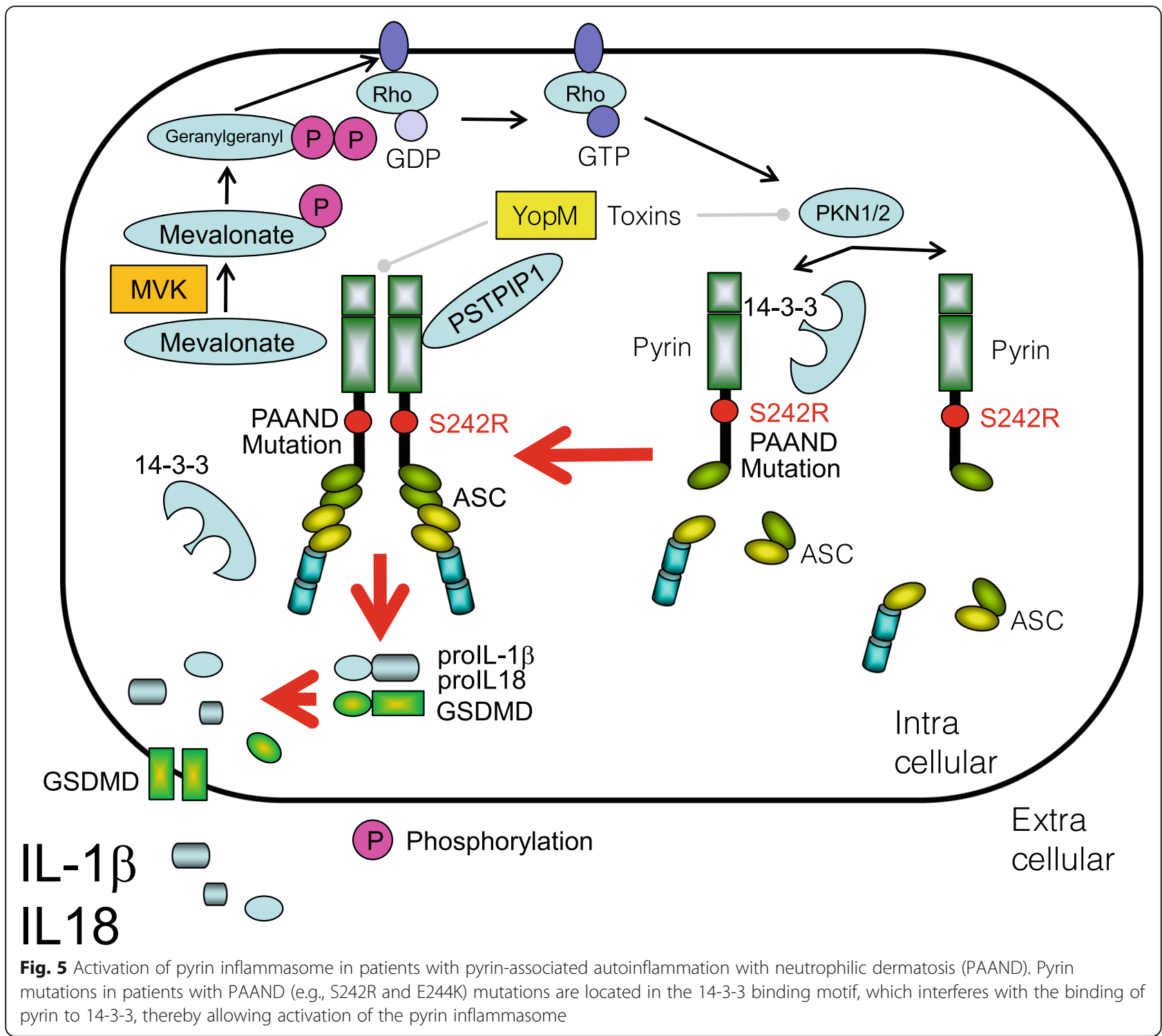

in turn activates IL-1 $\beta$ and IL-18. NLRC4 inflammasomopathies are linked more closely with hypersecretion of IL-18 rather than of IL-1 $\beta$; however, the precise mechanism remains to be elucidated [132] (Fig. 8). Corresponding common diseases caused by the similar signaling are shown in Table 1.

\section{NF-kB-related autoinflammatory diseases (relopathies)}

Dysregulations of NF- $\mathrm{kB}$ signaling are closely linking to the ubiquitination system. In addition to constitutive activation of NF-kB, loss-of-function mutations in the ubiquitin-mediated NF- $\mathrm{KB}$ regulatory system cause autoinflammatory diseases [10] (Fig. 9).
Blau syndrome/early-onset sarcoidosis

The gene responsible for Blau syndrome (BS)/early-onset sarcoidosis (EOS) is $I B D 1$, and its causative gene product is NOD2 [133]. Usually, NOD2 recognizes muramyl dipeptide (MDP), leading to activation of NF-kB. Currently, 185 variants of NOD2 have been reported (https://infevers.umai-montpellier.fr/web/search.php?n= 6). Gain-of-function mutations in NOD2 increase signaling via NOD2-RIPK2-associated activation of NF- $\mathrm{kB}$ [134, 135] (Fig. 10). Corresponding common diseases caused by the similar signaling are shown in Table 1.

\section{A20 protein haploinsufficiency}

A20 (also called TNF- $\alpha$-induced protein (TNFAIP) 3, is an intracellular deubiquitinase. A20 plays a role in 


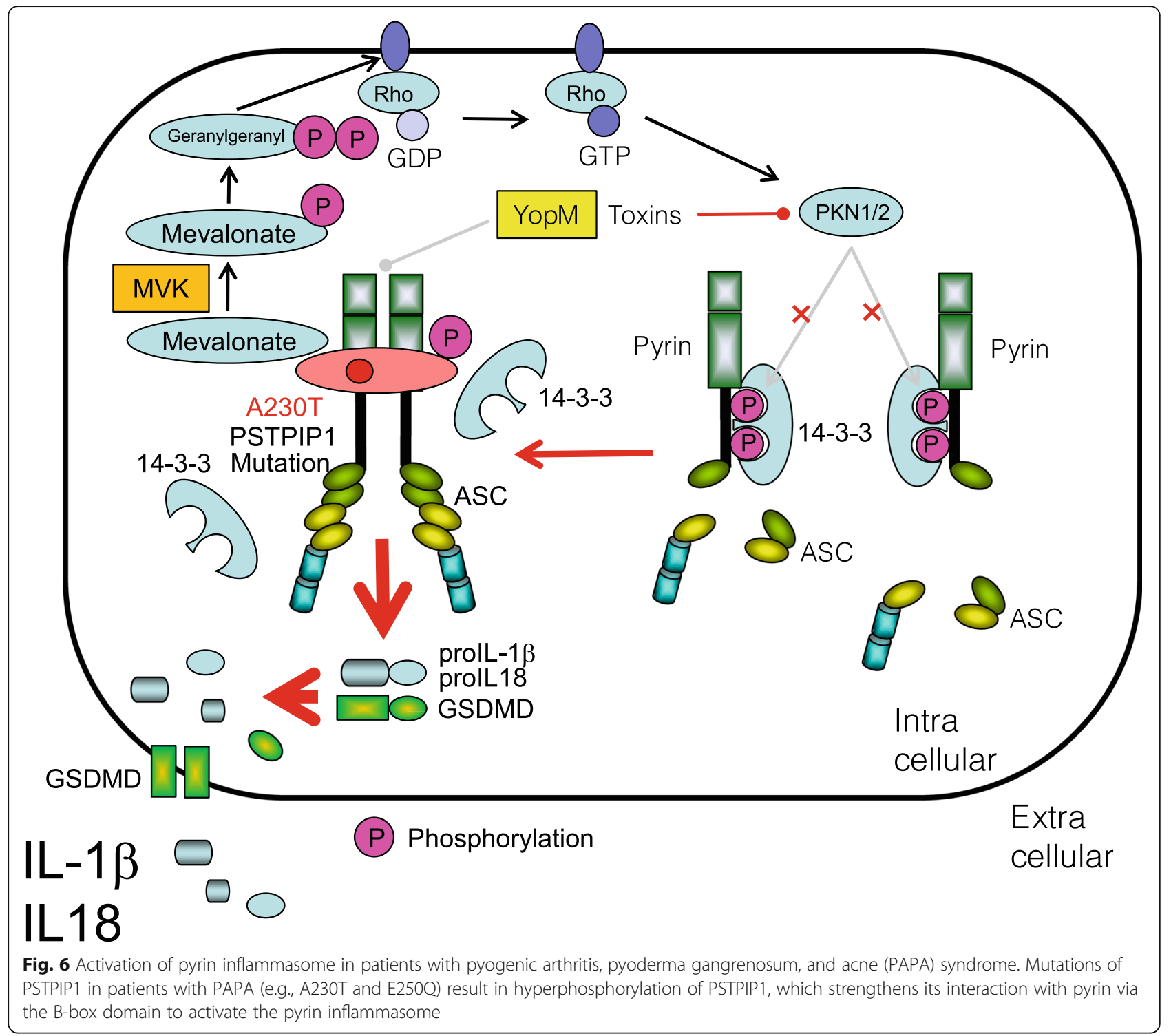

deubiquitination of several proteins, including NF- $\mathrm{BB}$. A20 protein haploinsufficiency (HA20) is caused by heterozygous mutation or deletion of A20, resulting in insufficient deubiquitination of TRAF6 downstream of the TNF- $\alpha$ pathway, RIPK1 downstream of the TLR pathway, and RIPK2 downstream of the NOD1 or NOD2 pathways. Loss of A20 function leads to constitutive activation of NF- $\mathrm{kB}$ signaling $[136,137]$. A20 also regulates the activity of the NLRP3 inflammasome in macrophages [138]. So far, 55 variants of A20 have been reported (https://infevers.umai-montpellier.fr/web/search.php?n= 26). Haplodeficient mutations severely reduce A20 function, leading to prolonged activation of NF- $k B$ [139] (Fig. 11). Corresponding common diseases caused by the similar signaling are shown in Table 1.
Immunodeficiency, autoinflammation, and amylopectinosis with inherited linear ubiquitin chain assembly complex deficiency

Loss-of-function mutation in linear ubiquitin chain assembly complex (LUBAC), a protein complex comprising heme-oxidized IRP2 ubiquitin ligase 1 (HOIL-1) (also called RBCK1), HOIL-1 interaction protein (HOIP, also called RNF31), and SHANK-associated RH domaininteracting protein (SHARPIN) is associated with autoinflammation [140-145]. The L72P mutation in the HOIP protein affects its interaction with OTU deubiquitinase with linear linkage specificity (OTULIN) and lysine 63 deubiquitinase (CYLD); however, the most common disease-causing phenomenon is loss of expression of the L72P allele of HOIP. Combined heteromutations 


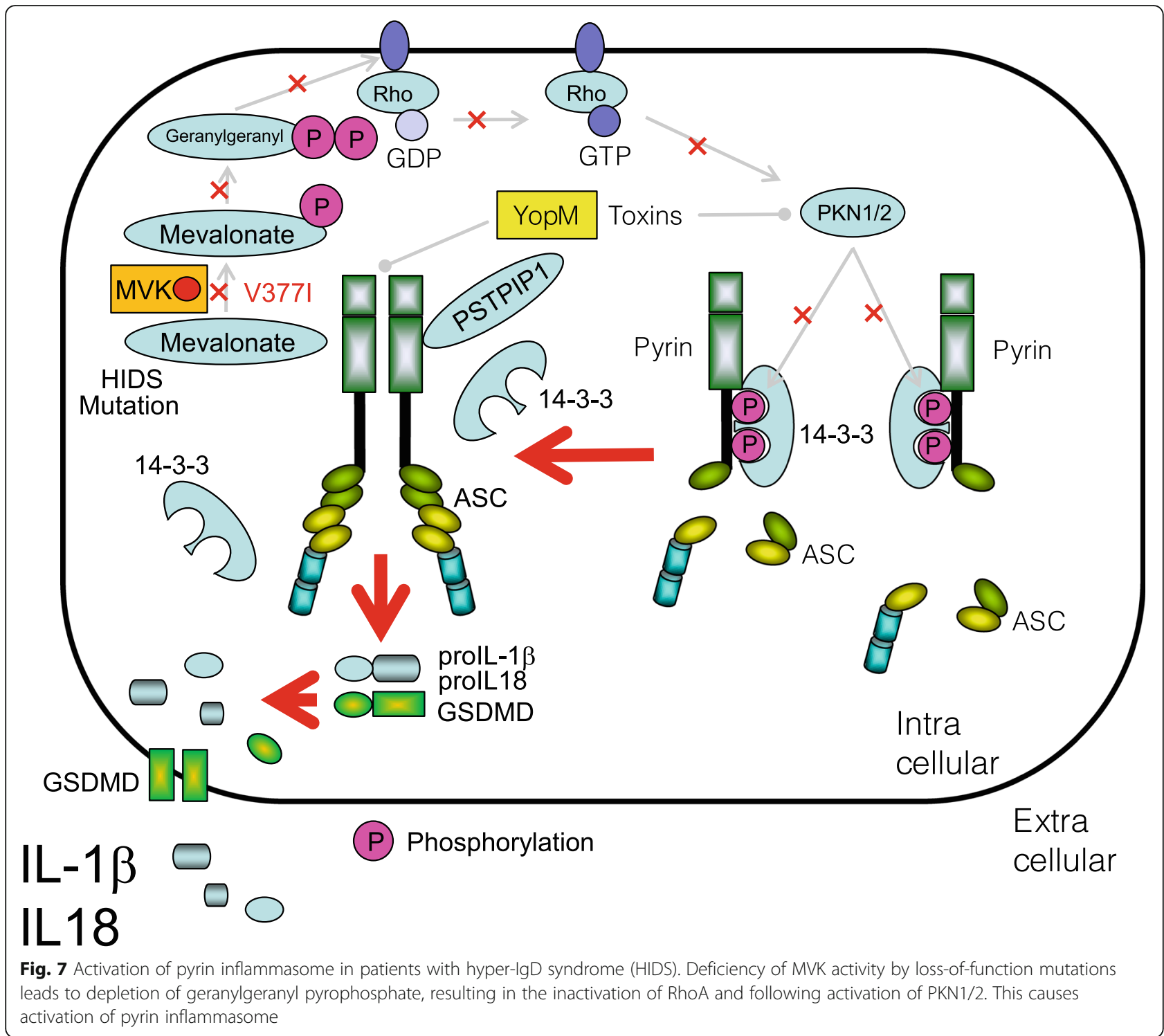

comprise L41fsX7 and Q185X, which result in deficient HOIL-1 expression. Lack of HOIL-1 expression by fibroblasts impairs phosphorylation of IKK kinase, slower degradation of $\mathrm{I} K \mathrm{~B} \alpha$, and decreased ubiquitination of NEMO in response to stimulation with either TNF- $\alpha$ or IL-1 $\beta$. LUBAC deficiency in fibroblasts downregulates NF- $\kappa B$ activation in response to IL- $1 \beta$ or TNF- $\alpha$, whereas deficient monocytes release more IL- 6 but less IL-10 in response to IL-1 $\beta$ [146-148] (Fig. 12). Corresponding common diseases caused by the similar signaling are shown in Table 1.

\section{OTULIN-related autoinflammatory syndrome}

OTULIN is a deubiquitination enzyme that hydrolyzes methionine-1 (M1), which links to liner ubiquitin chains to regulate the activity of NF- $\mathrm{kB}$ [149]. Homozygous loss-of-function mutations in OTULIN cause OTULINrelated autoinflammatory syndrome (ORAS) [150]. The L272P mutation is located in a helix of the catalytic OTU domain, which forms part of the binding pocket for M1-linked distal ubiquitin; this mutation disrupts the binding of OTULIN and ubiquitin to its substrate [151, 152] (Fig. 13). Corresponding common diseases caused by the similar signaling are shown in Table 1.

\section{IL-1 receptor-related autoinflammatory diseases}

IL-1 receptor-related autosomal recessive autoinflammatory diseases are caused by mutations in IL1RN (interleukin-1 receptor antagonist), resulting in a condition called deficiency of interleukin-1 receptor antagonist (DIRA) [153-155]. So far, 22 variants of this gene have been reported (https://infevers.umai-montpellier.fr/web/ 


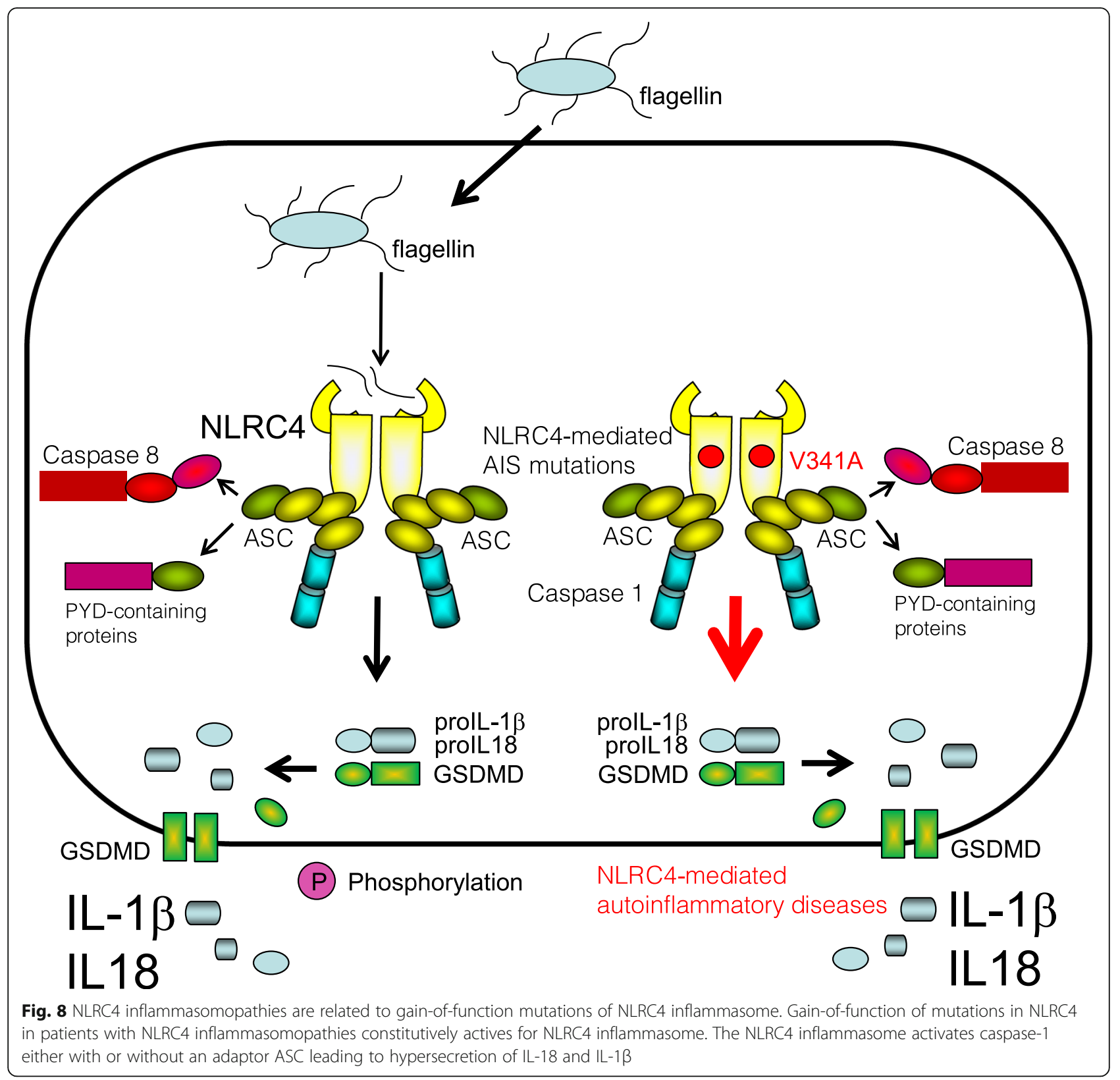

search.php? $n=10)$. IL-1RA deficiency results in uncontrolled IL-1 $\alpha$, IL-1 $\beta$ and NF-kB signaling [156] (Fig. 9). Corresponding common diseases caused by the similar signaling are shown in Table 1.

\section{Interferonopathies}

Anti-viral first-line defense is dependent on innate immune receptors (e.g., cGAS, MDA5, and RIG-I) that are detecting intracellular viral, bacterial, or own nucleic acid, linking to type I interferon signaling. Interferonopathies are closely linked to dysfunction of these innate immune receptors and type I interferon signaling, Immunoproteasome dysfunction is also linked to the interferonopathies [157] (Fig. 14).

\section{Aicardi-Goutières syndrome}

Aicardi-Goutières syndrome (AGS) is an inherited encephalopathy that affects newborn infants and usually results in severe neuro-physical disability. AGS is caused by loss-of-function mutations in the genes encoding the three prime repair exonuclease 1 (TREX1), the ribonuclease H2 subunit (RNASEH2)A, RNASEH2B, RNA$\mathrm{SEH} 2 \mathrm{C}$, the phosphohydrolase SAM domain and HD 


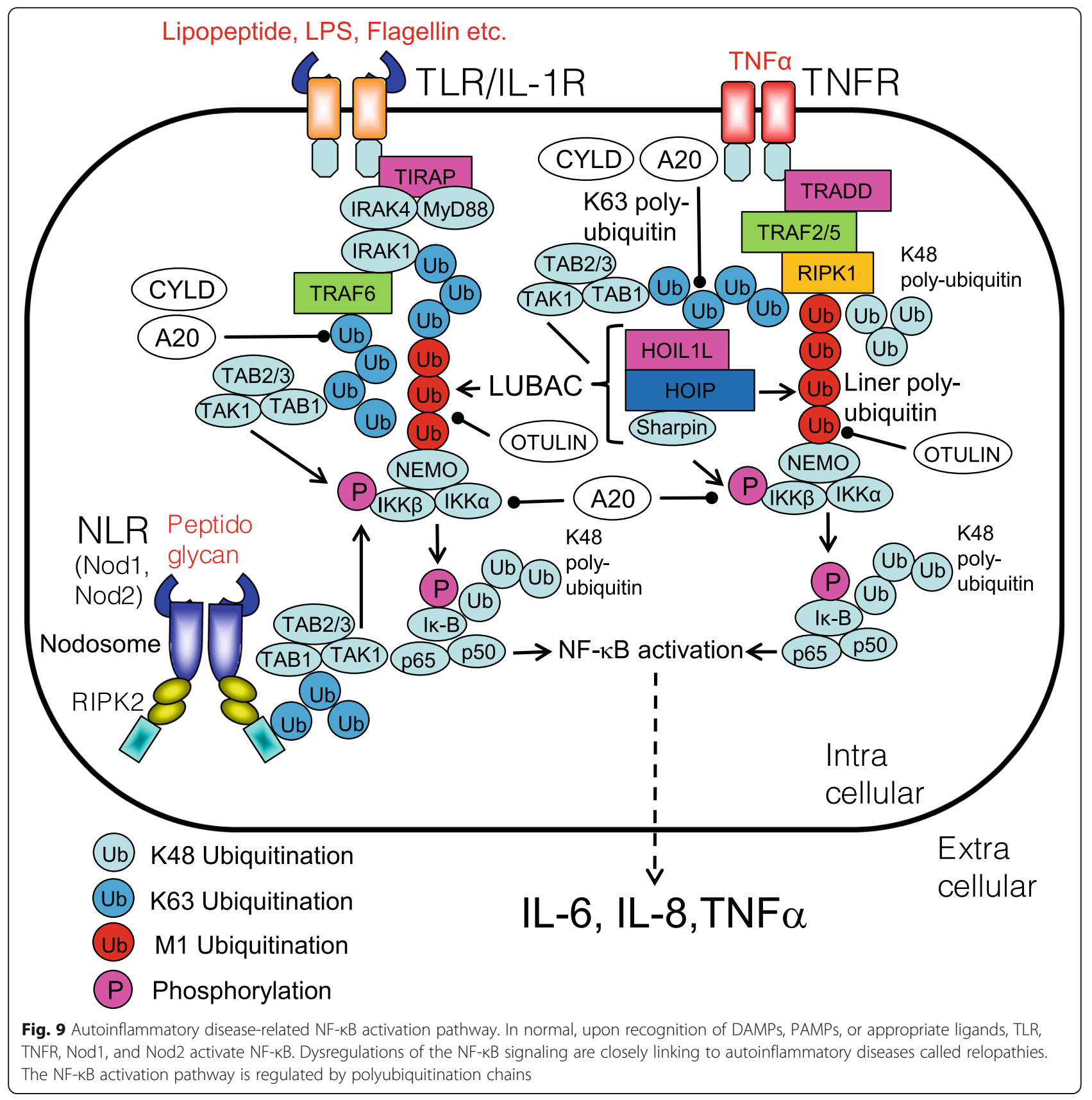

domain-containing protein 1 (SAMHD1), or the dsRNAspecific adenosine deaminases acting on RNA1 (ADAR1) $[158,159]$. In addition, gain-of-function mutations in the dsRNA sensor MDA5 (also called IFIH1) have been identified in AGS patients [157]. AGS pathology seems to be caused by the accumulation of nucleic acids, which can cause neurological and liver abnormalities that resemble congenital viral infection (Fig. 15). Corresponding common diseases caused by the similar signaling are shown in Table 1.
Stimulator of interferon gene-associated vasculopathy with onset in infancy

Stimulator of interferon gene (STING)-associated vasculopathy with onset in infancy (SAVI) is caused by gain-offunction mutations in STING (also called TMEM173). Mutation of the STING amplifies the function of STING, which is an adaptor molecule involved in signal transduction through cGAS, leading to hyperactivation of type I IFN pathways [160]. Corresponding common diseases caused by the similar signaling are shown in Table 1 . 


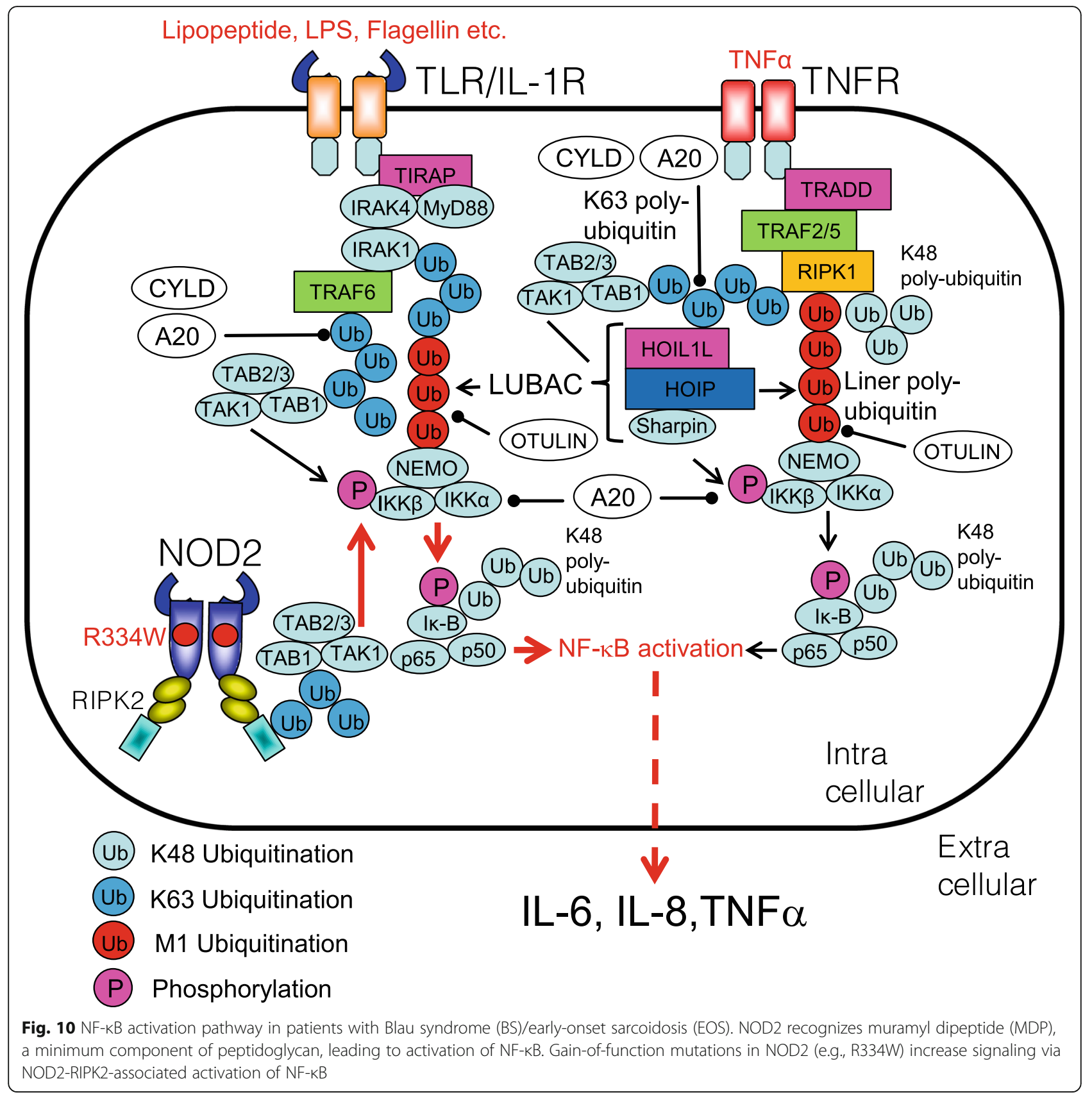

\section{Coatomer protein alpha syndromes}

Coatomer protein alpha (COPA) syndrome, characterized by high-titer autoantibodies, interstitial lung disease, and inflammatory arthritis, was found to be deleterious mutations in the COPA gene (encoding coatomer subunit $\alpha$ ). Mutant COPA causes defective intracellular transport via coat protein complex I which leads to ER stress and the upregulation of the levels of transcripts encoding IL-1 $\beta$, IL-6, and IL-23 [161]. COPA is a critical regulator of STING transport ER and retrieval of STING from the Golgi. Mutant COPA retention of STING on the Golgi resulting in STING activation leads to prolonged type I interferon signaling [86] (Fig. 16). Corresponding common diseases caused by the similar signaling are shown in Table 1.

Proteasome-associated autoinflammatory syndromes Nakajo-Nishimura syndrome (NNS) and chronic atypical neutrophilic dermatosis with lipodystrophy and elevated temperature syndrome (CANDLE) were the first 


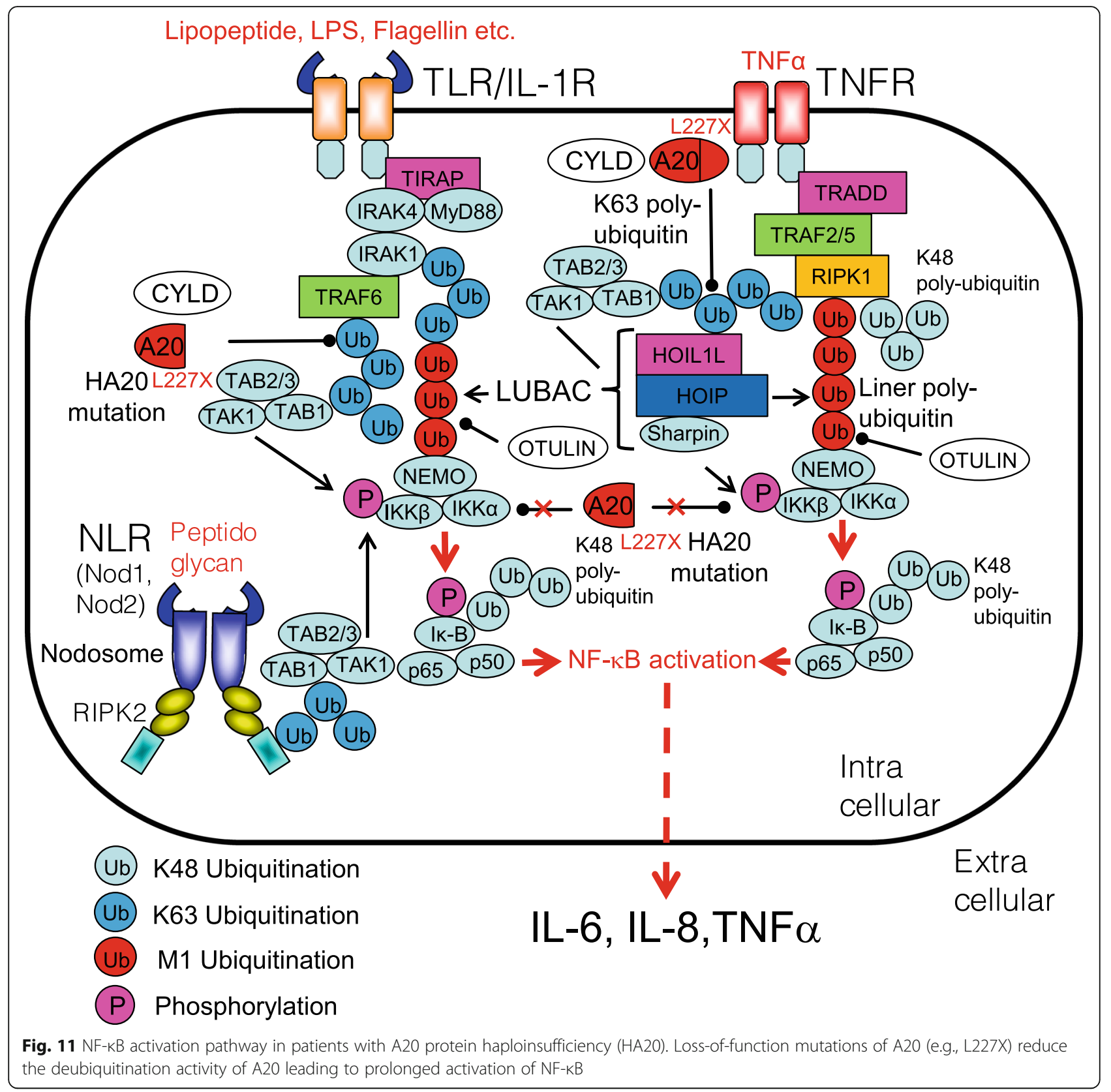

PRAAS to be described. Loss-of-function mutation in immunoproteasome components such as proteasome subunit beta type (PSMB)8, PSMB4, PSMA3, PSMB9, or proteasome maturation protein (POMP) leads to increased secretion of type I IFN by immune cells [162, 163] (Fig. 17). Corresponding common diseases caused by the similar signaling are shown in Table 1.

\section{Singleton-Merten syndrome}

Singleton-Merten syndrome (SMS) is caused by gain-offunction mutations in the RNA sensor MDA5 or RIG-I. Typical SMS is caused by a mutation in MDA5, whereas atypical SMS is caused by a mutation in RIG-I; both mutations cause constitutive activation of IFN signaling pathways $[164,165]$. Notably, mutations in the MDA5 are also associated with AGS, so that both SMS and AGS share a common molecular mechanism [164] (Fig. 18). Corresponding common diseases caused by the similar signaling are shown in Table 1 .

\section{Conclusions}

Here, we describe briefly the molecular mechanisms underlying autoinflammatory diseases caused by dysregulation of IL- $1 \beta$ or IL-18 processing, NF- $\kappa B$ activation, 


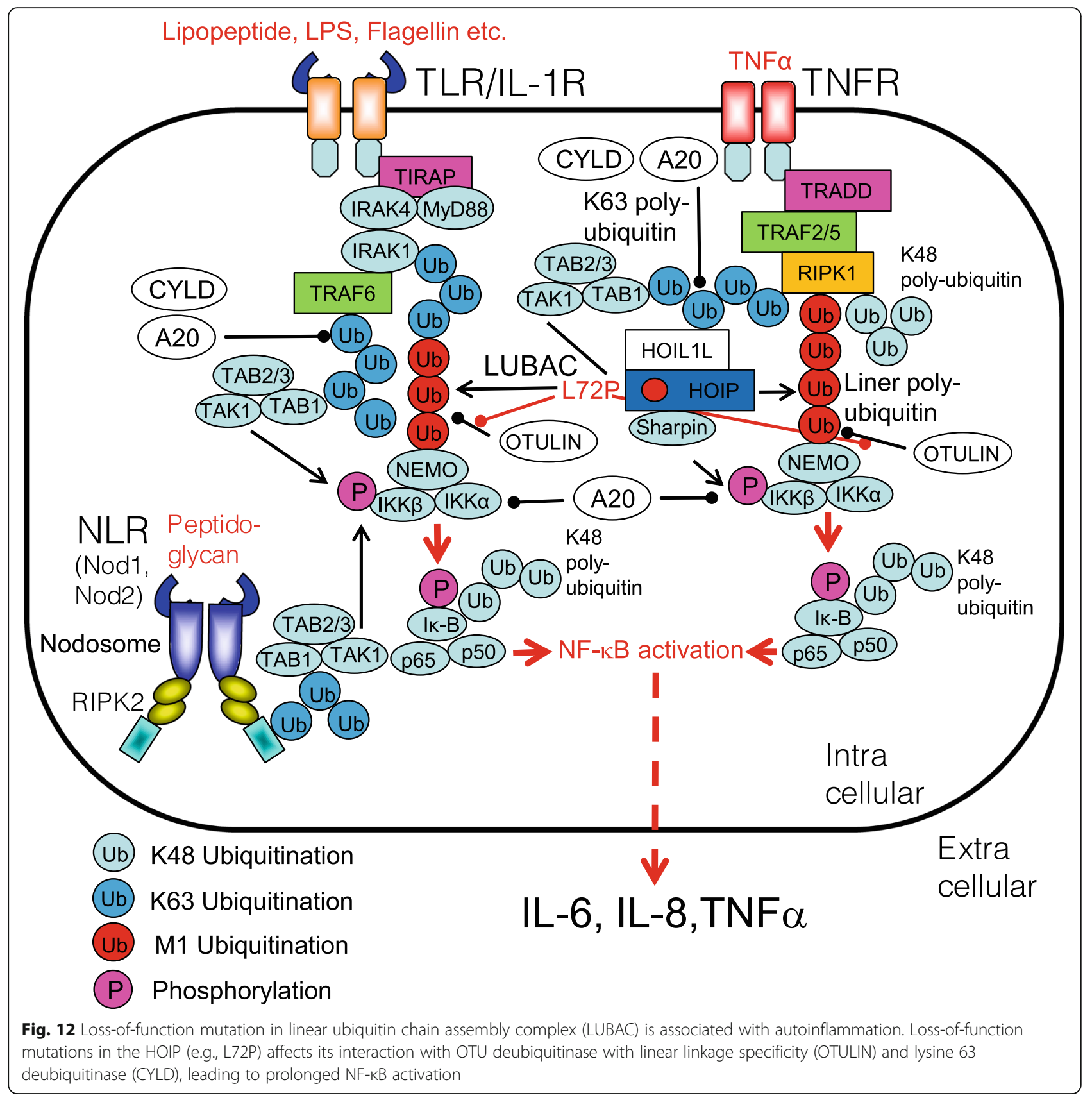




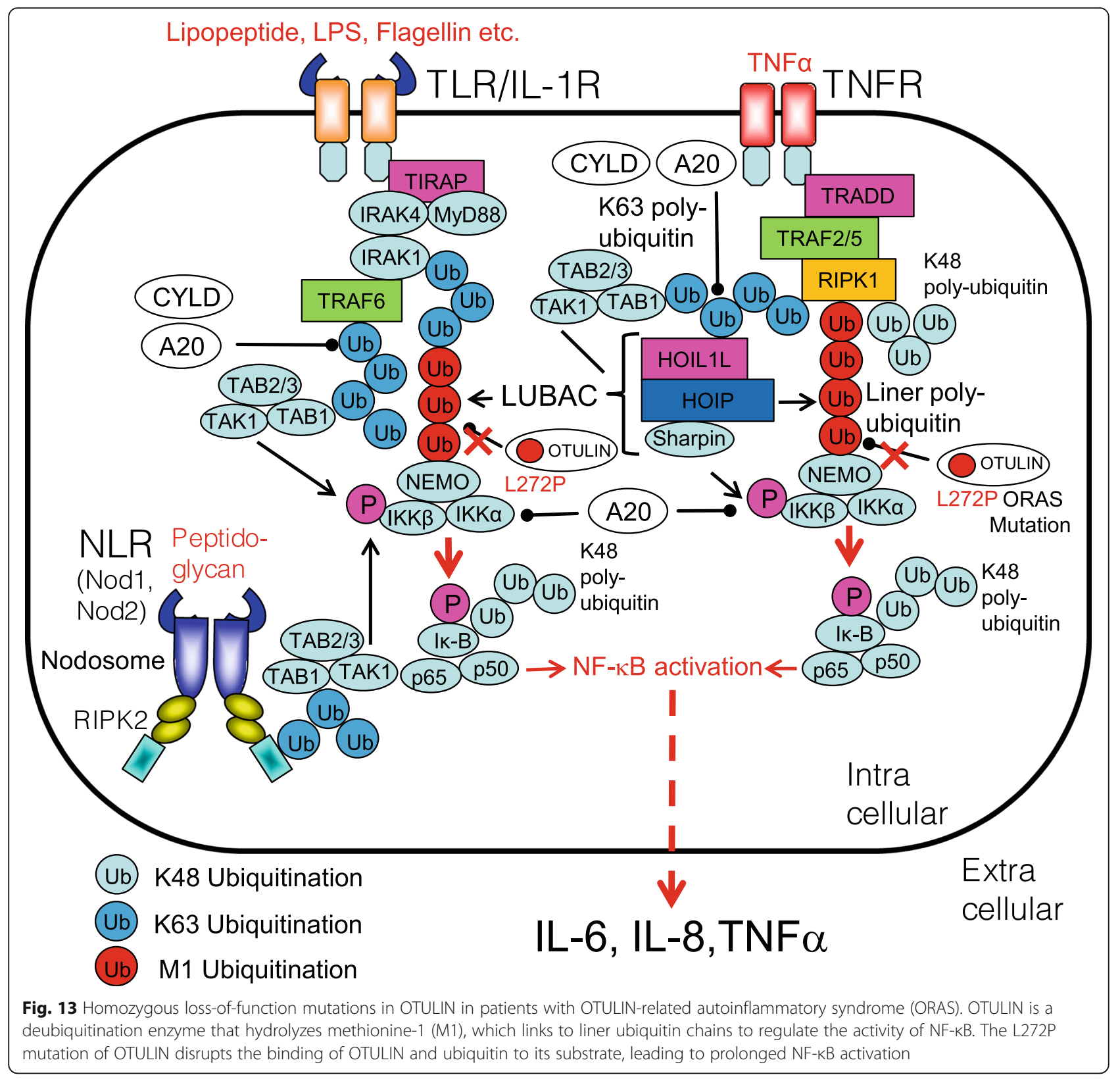




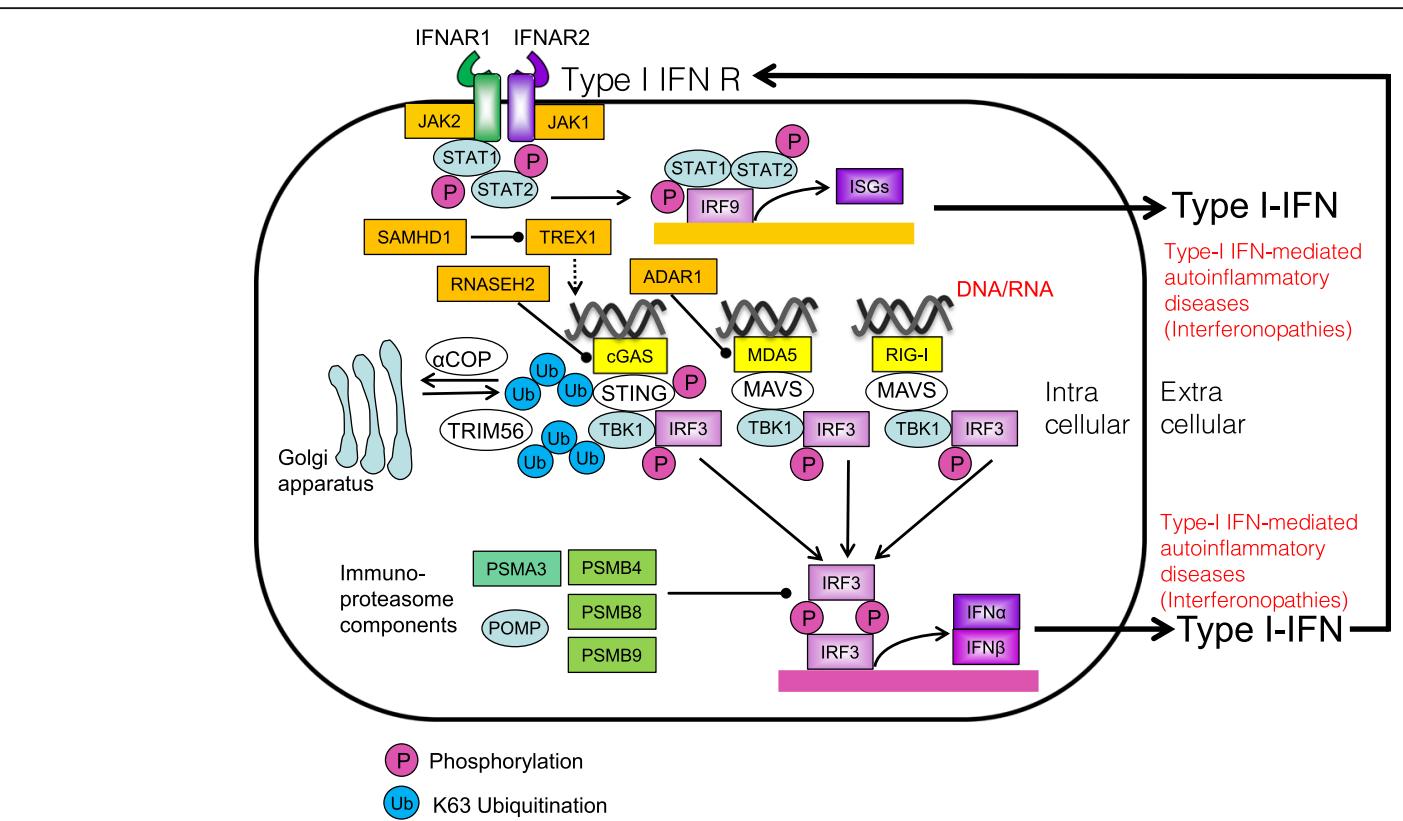

Fig. 14 Type I interferon signaling in interferonopathies. Type I interferon singling is closely linked to innate immune receptors such as cGAS, MDA5, and RIG-I that are sensing viral, bacterial, or own DNA or RNA. Interferon-stimulated genes (ISGS) are induced by interferon regulatory factors (IRFs) downstream of CGAS, MDA5, and RIG-I. Immunoproteasome dysfunction is also linked to interferonopathies

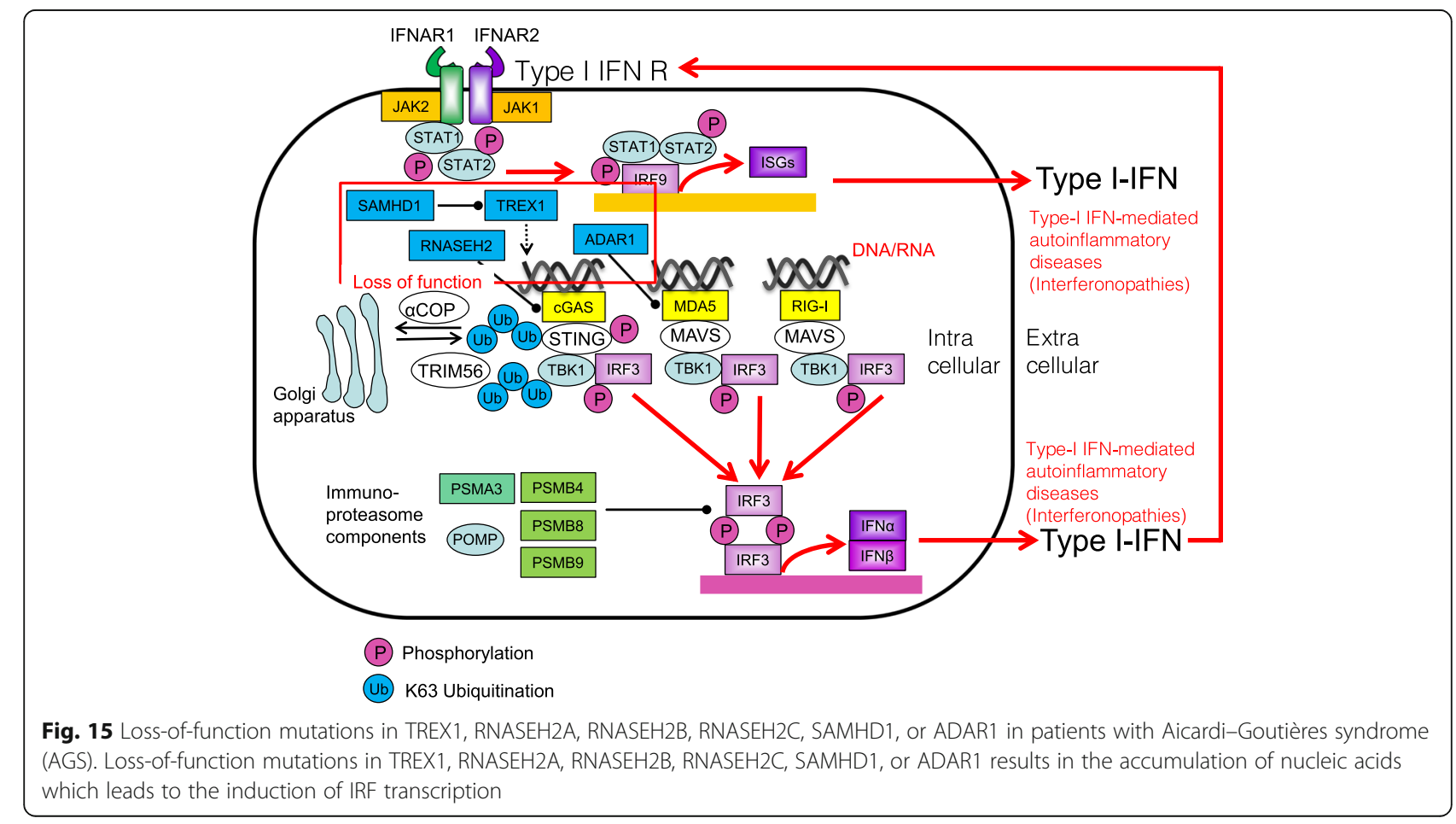




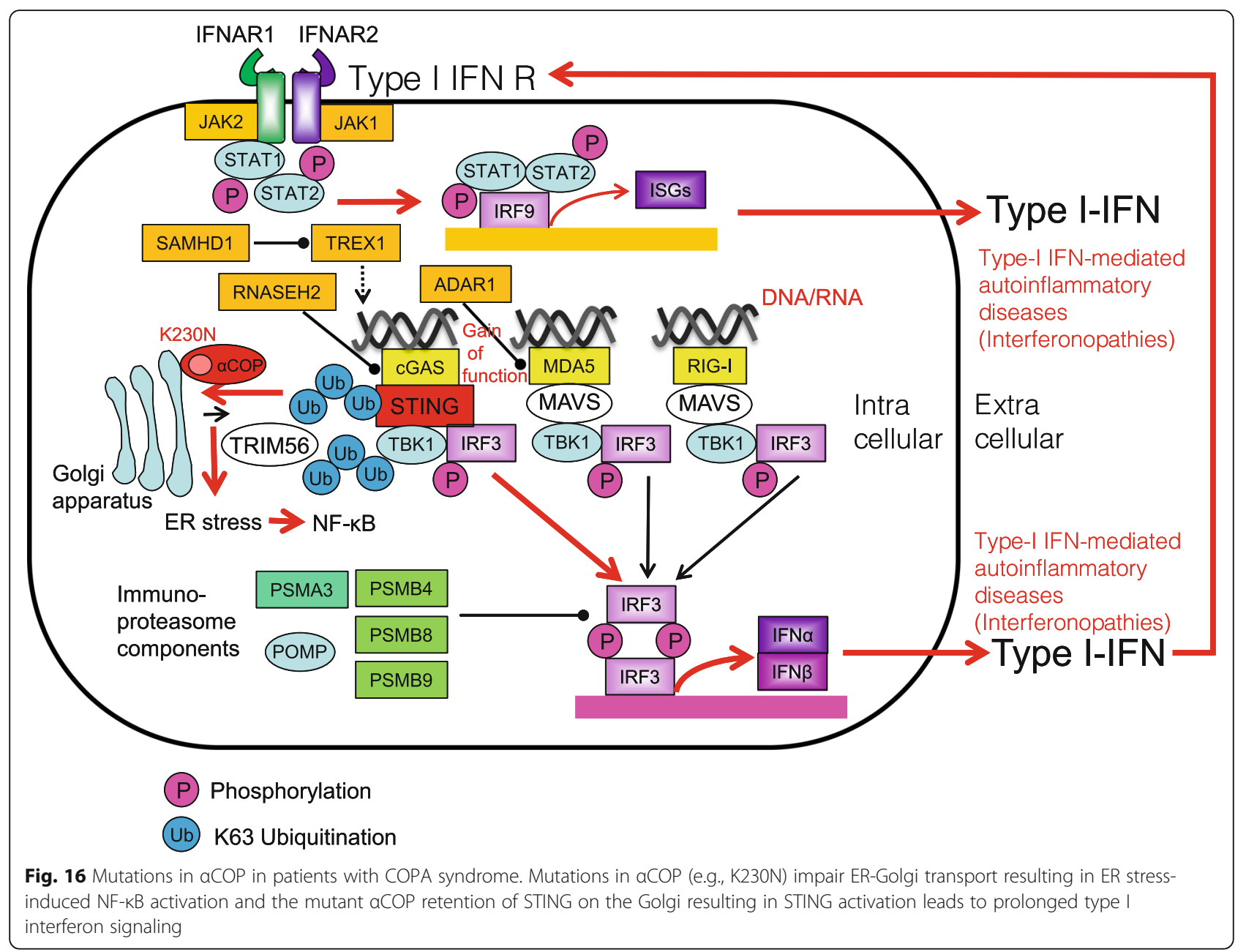




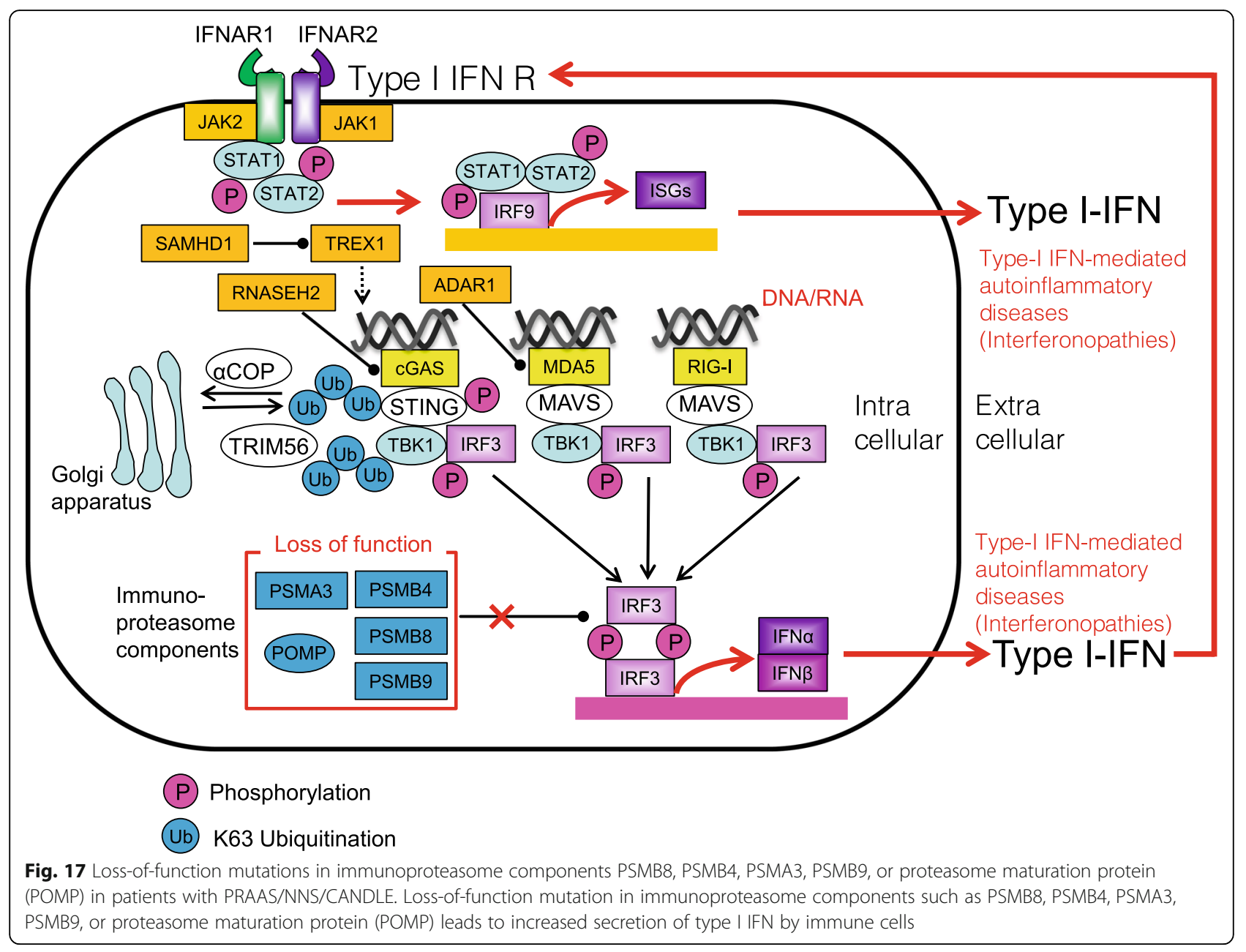




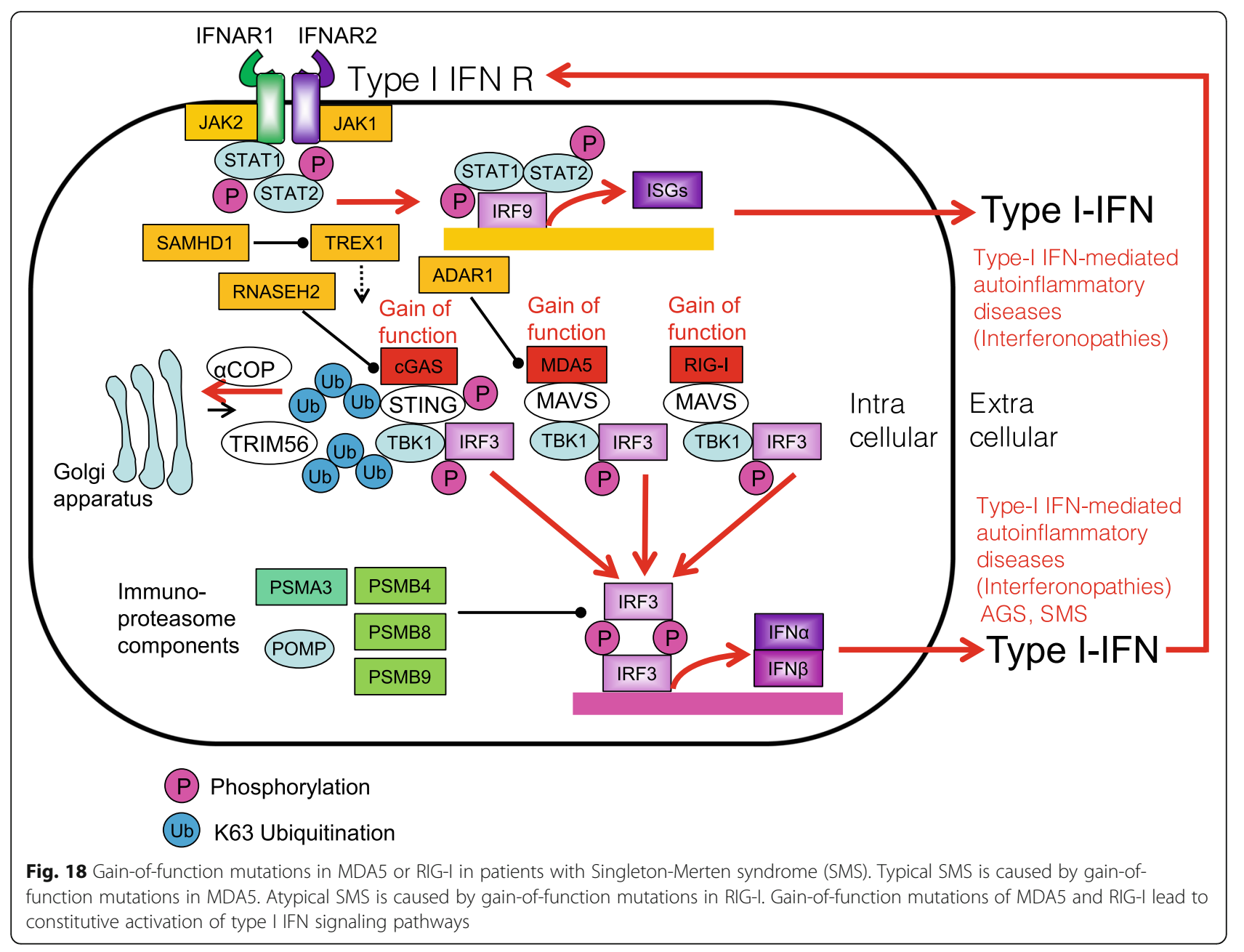

and IFN secretion. Disruption of the fine balance within these signaling pathways contributes to the pathogenesis of autoinflammatory diseases. Increasing our knowledge of the molecular biology underlying autoinflammatory diseases will facilitate the development of diseasetargeting biologics. Therefore, future studies should elucidate the autoinflammatory disease-specific signalosome in detail.

\footnotetext{
Abbreviations

DAMP: Damage-associated molecular pattern; PAMP: Pathogen-associated molecular pattern; PRR: Pattern recognition receptor; TLR: Toll-like receptor; NLR: NOD-like receptor; CLR: C-type lectin receptor; RLR: RIG-Ilike receptor; NF: Nuclear factor; PRAAS: Proteasome-associated autoinflammatory syndromes; IL: Interleukin; PYD: Pyrin domain; AIM2: Absent in melanoma 2; ASC: Apoptosis-associated speck-like protein containing a caspaserecruitment domain; CARD: Caspase-recruitment domain; GSDMD: Gasdermin D; CAPS: Cryopyrin-associated periodic syndrome; FCAS: Familial cold autoinflammatory syndrome; FCU: Familial cold urticaria; MWS: Muckle-Wells syndrome; NOMID: Neonatal-onset multisystem inflammatory disease; CINCA: Chronic infantile neurologic, cutaneous, and arthritis; NAIAD: NLRP1associated autoinflammation with arthritis and dyskeratosis; NLRP12AD: NLRP12 autoinflammatory syndrome; TNF: Tumor necrosis factor; TRAPS: TNF receptor-associated periodic fever syndrome; TNFRSF: TNF
}

receptor superfamily member; APLAID: Autoinflammation and PLCY2associated antibody deficiency and immune dysregulation; FMF: Familial Mediterranean fever; PFIT: Periodic fever immunodeficiency and thrombocytopenia; PAAND: Pyrin-associated autoinflammation with neutrophilic dermatosis; PAPA: Pyogenic arthritis, pyoderma gangrenosum, and acne; PSTPIP1: Proline-serine-threonine phosphatase-interacting protein 1; CD2BP1: CD2-binding protein 1; MKD: Mevalonate kinase deficiency; HIDS: Hyperimmunoglobulinemia D and periodic fever syndrome; MVK: Mevalonate kinase; MAS: Macrophage activation syndrome; BS: Blau syndrome; EOS: Early-onset sarcoidosis; MDP: Muramyl dipeptide; HA20: A20 protein haploinsufficiency; TNFAIP: Tumor necrosis factor alpha-induced protein; IAALUCD: Immunodeficiency, autoinflammation, and amylopectinosis with inherited linear ubiquitin chain assembly complex deficiency; LUBAC: Linear ubiquitin chain assembly complex; HOIL-1: Heme-oxidized IRP2 ubiquitin ligase 1; HOIP: HOIL-1 interaction protein; SHARPIN: SHANKassociated RH domain-interacting protein; OTULIN: OTU deubiquitinase with linear linkage specificity; CYLD: CYLD lysine 63 deubiquitinase;

ORAS: OTULIN-related autoinflammatory syndrome; DIRA: Deficiency of the IL-1-receptor antagonist; AGS: Aicardi-Goutières syndrome; TREX: Three prime repair exonuclease; RNASEH2: Ribonuclease H2 subunit; SAMHD: SAM domain and HD domain-containing protein; ADAR1: dsRNA-specific adenosine deaminases acting on RNA 1; STING: Stimulator of interferon genes; SAVI: STING-associated vasculopathy with onset in infancy; COPA: Coatomer protein alpha; NNS: Nakajo-Nishimura syndrome; CANDLE: Chronic atypical neutrophilic dermatosis with lipodystrophy and 
elevated temperature syndrome; PSMB: Proteasome subunit beta type; POMP: Proteasome maturation protein; SMS: Singleton-Merten syndrome

\section{Acknowledgements}

We greatly appreciate Dr. Isabelle Touitou, chief editor of "INFEVERS"

database, and its contributors.

\section{Authors' contributions}

The manuscript was written by NK and JM. All authors read and approved the final manuscript.

\section{Funding}

This work was supported by Grants-in-Aid for Scientific Research (B) (JSPS KAKENHI Grant Number: $20 \mathrm{H} 03719$ to JM) and Grant-in-Aid for Encouragement of Scientists (JSPS KAKENHI Grant Number: $20 \mathrm{H} 01085$ to NK).

\section{Availability of data and materials}

Not applicable.

\section{Declarations}

Ethics approval and consent to participate

Not applicable.

\section{Consent for publication}

Not applicable.

\section{Competing interests}

All authors declare no competing interests.

Received: 23 February 2021 Accepted: 9 September 2021

\section{Published online: 11 October 2021}

\section{References}

1. Kumar V, Abbas AK, Aster JC. Robbins \& Cotran pathologic basis of disease. 9th ed. Amsterdam: Elsevier B.V; 2015

2. Hotamisligil GS. Inflammation and metabolic disorders. Nature. 2006; 444(7121):860-7. https://doi.org/10.1038/nature05485.

3. Hotamisligil GS. Endoplasmic reticulum stress and the inflammatory basis of metabolic disease. Cell. 2010;140(6):900-17. https://doi.org/10.1016/j.cell.201 0.02 .034 .

4. Gregor MF, Hotamisligil GS. Inflammatory mechanisms in obesity. Annu Rev Immunol. 2011;29(1):415-45. https://doi.org/10.1146/annurev-immunol031210-101322.

5. Janeway CA Jr. Approaching the asymptote? Evolution and revolution in immunology. Cold Spring Harb Symp Quant Biol. 1989;54(Pt 1):1-13. https:// doi.org/10.1101/sqb.1989.054.01.003.

6. Tang T, Gong T, Jiang W, Zhou R. GPCRs in NLRP3 Inflammasome activation, regulation, and therapeutics. Trends Pharmacol Sci. 2018;39(9):798-811. https://doi.org/10.1016/j.tips.2018.07.002.

7. Masters SL, Simon A, Aksentijevich I, Kastner DL. Horror autoinflammaticus: the molecular pathophysiology of autoinflammatory disease $\left(^{*}\right)$. Annu Rev Immunol. 2009;27(1):621-68. https://doi.org/10.1146/annurev.immunol.25. 022106.141627.

8. Jones JF, Minnich LM, Lucas DO, Langford MP, Stanton GJ. Does an interferonopathy underlie a severe combined immunodeficiency disease (SCID) syndrome? Birth Defects Orig Artic Ser. 1983;19(3):109-14.

9. Crow YJ. Type I interferonopathies: a novel set of inborn errors of immunity. Ann N Y Acad Sci. 2011;1238(1):91-8. https://doi.org/10.1111/j.1749-6632.2 011.06220.x

10. Moghaddas F, Masters SL. Monogenic autoinflammatory diseases: Cytokinopathies. Cytokine. 2015;74(2):237-46. https://doi.org/10.1016/j.cyto.2 015.02.012.

11. McDermott A, Jacks J, Kessler M, Emanuel PD, Gao L. Proteasome-associated autoinflammatory syndromes: advances in pathogeneses, clinical presentations, diagnosis, and management. Int J Dermatol. 2015;54(2):121-9. https://doi.org/10.1111/ijd.12695.

12. McDermott MF, Aksentijevich I, Galon J, McDermott EM, Ogunkolade BW, Centola $\mathrm{M}$, et al. Germline mutations in the extracellular domains of the 55 kDa TNF receptor, TNFR1, define a family of dominantly inherited autoinflammatory syndromes. Cell. 1999;97:133-44. https://doi.org/10.1016/ s0092-8674(00)80721-7.

13. Poyet JL, Razmara M, Datta P, Zhang Z, Alnemri ES. The PYRIN-CARD protein ASC is an activating adaptor for caspase-1. Srinivasula SM, J Biol Chem. 2002;277:21119-21122. doi: https://doi.org/10.1074/jbc.C200179200, 24.

14. Martinon F, Burns K, Tschopp J. The inflammasome: a molecular platform triggering activation of inflammatory caspases and processing of prolL- $\beta$. Mol Cell. 2002;10(2):417-26. https://doi.org/10.1016/S1097-2765(02)00599-3.

15. Bruey JM, Bruey-Sedano N, Newman R, Chandler S, Stehlik C, Reed JC. PAN1/NALP2/PYPAF2, an inducible inflammatory mediator that regulates NF-kB and caspase-1 activation in macrophages. J Biol Chem. 2004;279(50): 51897-907. https://doi.org/10.1074/jbc.M406741200.

16. Manji GA, Wang L, Geddes BJ, Brown M, Merriam S, Al-Garawi A, et al. PYPA F1, a PYRIN-containing Apaf1-like protein that assembles with ASC and regulates activation of NF-kappa B. J Biol Chem. 2002;277(13):11570-5. https://doi.org/10.1074/jbc.M112208200

17. Agostini L, Martinon F, Burns K, McDermott MF, Hawkins PN, Tschopp J. NALP3 forms an IL-1 $\beta$-processing inflammasome with increased activity in Muckle-Wells autoinflammatory disorder. Immunity. 2004;20(3):319-25. https://doi.org/10.1016/s1074-7613(04)00046-9.

18. Grenier JM, Wang L, Manji GA, Huang WJ, Al-Garawi A, Kelly R, et al. Functional screening of five PYPAF family members identifies PYPAF5 as a novel regulator of NF-kappaB and caspase-1. FEBS Lett. 2002;530(1-3):73-8. https://doi.org/10.1016/s0014-5793(02)03416-6.

19. Wang L, Manji GA, Grenier JM, Al-Garawi A, Merriam S, Lora JM, et al. PYPA F7, a novel PYRIN-containing Apaf1-like protein that regulates activation of NF-kB and caspase-1-dependent cytokine processing. J Biol Chem. 2002 277(33):29874-80. https://doi.org/10.1074/jbc.M203915200.

20. Ngo C, Man SM. NLRP9b: a novel RNA-sensing inflammasome complex. Cell Res. 2017:27(11):1302-3. https://doi.org/10.1038/cr.2017.93.

21. Zhu S, Ding S, Wang P, Wei Z, Pan W, Palm NW, et al. Nlrp9b inflammasome restricts rotavirus infection in intestinal epithelial cells. Nature. 2017; 546(7660):667-70. https://doi.org/10.1038/nature22967.

22. Antushevich $\mathrm{H}$. Interplays between inflammasomes and viruses, bacteria (pathogenic and probiotic), yeasts and parasites. Immunol Lett. 2020;228:114. https://doi.org/10.1016/j.imlet.2020.09.004.

23. DeYoung KL, Ray ME, Su YA, Anzick SL, Johnstone RW, Trapani JA, et al. Cloning a novel member of the human interferon-inducible gene family associated with control of tumorigenicity in a model of human melanoma. Oncogene. 1997;15(4):453-7. https://doi.org/10.1038/sj.onc.1201206.

24. Bürckstümmer T, Baumann C, Blüml S, Dixit E, Dürnberger $G$, Jahn $H$, et al. An orthogonal proteomic-genomic screen identifies AIM2 as a cytoplasmic DNA sensor for the inflammasome. Nat Immunol. 2009;10(3):266-72. https:// doi.org/10.1038/ni.1702.

25. Fernandes-Alnemri T, Yu JW, Datta P, Wu J, Alnemri ES. AIM2 activates the inflammasome and cell death in response to cytoplasmic DNA. Nature. 2009:458(7237):509-13. https://doi.org/10.1038/nature07710.

26. Hornung V, Ablasser A, Charrel-Dennis M, Bauernfeind F, Horvath G, Caffrey DR, et al. AIM2 recognizes cytosolic dsDNA and forms a caspase-1-activating inflammasome with ASC. Nature. 2009;458(7237):514-8. https://doi.org/10.1 038/nature07725.

27. Schroder K, Muruve DA, Tschopp J. Innate immunity: cytoplasmic DNA sensing by the AIM2 inflammasome. Curr Biol. 2009;19(6):R262-5. https:// doi.org/10.1016/j.cub.2009.02.011

28. Choubey D, Duan X, Dickerson E, Ponomareva L, Panchanathan R, Shen $H$ et al. Interferon-inducible p200-family proteins as novel sensors of cytoplasmic DNA: role in inflammation and autoimmunity. J Interf Cytokine Res. 2010;30(6):371-80. https://doi.org/10.1089/jir.2009.0096.

29. Kerur N, Veettil MV, Sharma-Walia N, Bottero V, Sadagopan S, Otageri P, et al. IFl16 acts as a nuclear pathogen sensor to induce the inflammasome in response to Kaposi Sarcoma-associated herpesvirus infection. Cell Host Microbe. 2011;9(5):363-75. https://doi.org/10.1016/j.chom.2011.04.008.

30. Poyet JL, Srinivasula SM, Tnani M, Razmara M, Fernandes-Alnemri T, Alnemri ES. Identification of Ipaf, a human caspase-1-activating protein related to Apaf-1. J Biol Chem. 2001;276(30):28309-13. https://doi.org/10.1074/jbc.C1 00250200

31. Razmara M, Srinivasula SM, Wang L, Poyet $J$, Geddes BJ, DiStefano PS, et al CARD-8 protein, a new CARD family member that regulates caspase-1 activation and apoptosis. J Biol Chem. 2002;277(16):13952-8. https://doi. org/10.1074/jbc.M107811200 
32. Taabazuing CY, Griswold AR, Bachovchin DA. The NLRP1 and CARD8 inflammasomes. Immunol Rev. 2020;297(1):13-25. https://doi.org/10.1111/ imr.12884.

33. Shi J, Zhao $Y$, Wang $K$, Shi $X$, Wang $Y$, Huang $H$, et al. Cleavage of GSDMD by inflammatory caspases determines pyroptotic cell death. Nature. 2015; 526(7575):660-5. https://doi.org/10.1038/nature15514.

34. Kayagaki N, Stowe IB, Lee BL, O'Rourke K, Anderson K, Warming S, et al. Caspase-11 cleaves gasdermin D for non-canonical inflammasome signalling. Nature. 2015;526(7575):666-71. https://doi.org/10.1038/nature15541.

35. Sarrauste de Menthière $C$, Terrière $S$, Pugnère $D$, Ruiz $M$, Demaille J, Touitou I. INFEVERS: the registry for FMF and hereditary inflammatory disorders mutations. Nucleic Acids Res. 2003;31:282-5. https://doi.org/10.1093/nar/ gkg031.

36. Hoffman HM, Mueller $\mathrm{J}$, Broide DH, Wanderer AA, Kolodner RD. Mutation of a new gene encoding a putative pyrin-like protein causes familial cold autoinflammatory syndrome and Muckle-Wells syndrome. Nat Genet. 2001; 29(3):301-5. https://doi.org/10.1038/ng756.

37. Neven B, Callebaut I, Prieur AM, Feldmann J, Bodemer C, Lepore L, et al. Molecular basis of the spectral expression of CIAS1 mutations associated with phagocytic cell-mediated autoinflammatory disorders CINCA/NOMID, MWS, and FCU. Blood. 2004;103(7):2809-15. https://doi.org/10.1182/blood-2 003-07-2531.

38. Dowds TA, Masumoto J, Zhu L, Inohara N, Núñez G. Cryopyrin-induced interleukin $1 \beta$ secretion in monocytic cells: enhanced activity of diseaseassociated mutants and requirement for ASC. J Biol Chem. 2004;279(21): 21924-8. https://doi.org/10.1074/jbc.M401178200.

39. Fujisawa A, Kambe N, Saito M, Nishikomori R, Tanizaki H, Kanazawa N, et al. Disease-associated mutations in CIAS1 induce cathepsin B-dependent rapid cell death of human THP-1 monocytic cells. Blood. 2007;109(7):2903-11. https://doi.org/10.1182/blood-2006-07-033597.

40. Saito M, Nishikomori R, Kambe N, Fujisawa A, Tanizaki H, Takeichi K, et al. Disease-associated CIAS1 mutations induce monocyte death, revealing lowlevel mosaicism in mutation-negative cryopyrin-associated periodic syndrome patients. Blood. 2008;111(4):2132-41. https://doi.org/10.1182/ blood-2007-06-094201.

41. Yamazaki T, Masumoto J, Agematsu K, Sawai N, Kobayashi S, Shigemura T, et al. Anakinra improves sensory deafness in a Japanese patient with Muckle-Wells syndrome, possibly by inhibiting the cryopyrin inflammasome. Arthritis Rheum. 2008;58(3):864-8. https://doi.org/10.1002/art.23261.

42. Martinon F, Pétrilli V, Mayor A, Tardivel A, Tschopp J. Gout-associated uric acid crystals activate the NALP3 inflammasome. Nature. 2006;440(7081):23741. https://doi.org/10.1038/nature04516.

43. Duewell P, Kono H, Rayner KJ, Sirois CM, Vladimer G, Bauernfeind FG, et al. NLRP3 inflammasomes are required for atherogenesis and activated by cholesterol crystals. Nature. 2010;464(7293):1357-61. https://doi.org/10.1038/ nature08938.

44. Masters SL, Dunne A, Subramanian SL, Hull RL, Tannahill GM, Sharp FA, et al. Activation of the NLRP3 inflammasome by islet amyloid polypeptide provides a mechanism for enhanced IL-1 beta in type 2 diabetes. Nat Immunol. 2010;11(10):897-904. https://doi.org/10.1038/ni.1935.

45. Heneka MT, Kummer MP, Stutz A, Delekate A, Schwartz S, Vieira-Saecker A, et al. NLRP3 is activated in Alzheimer's disease and contributes to pathology in APP/PS1 mice. Nature. 2013;493(7434):674-8. https://doi.org/1 0.1038/nature11729.

46. Saresella M, La Rosa F, Piancone F, Zoppis M, Marventano I, Calabrese E, et al. The NLRP3 and NLRP1 inflammasomes are activated in Alzheimer's disease. Mol Neurodegener. 2016;11(1):23. https://doi.org/10.1186/s13024-01 6-0088-1.

47. Codolo G, Plotegher N, Pozzobon T, Brucale M, Tessari I, Bubacco L, et al. Triggering of inflammasome by aggregated a-synuclein, an inflammatory response in synucleinopathies. PLoS One. 2013;8(1):e55375. https://doi.org/1 0.1371/journal.pone.0055375.

48. Johann S, Heitzer M, Kanagaratnam M, Goswami A, Rizo T, Weis J, et al. NLRP3 inflammasome is expressed by astrocytes in the SOD1 mouse model of ALS and in human sporadic ALS patients. Glia. 2015;63(12):2260-73. https://doi.org/10.1002/glia.22891.

49. Inoue M, Shinohara ML. NLRP3 Inflammasome and MS/EAE. Autoimmune Dis. 2013;2013:859145-8. https://doi.org/10.1155/2013/859145.

50. Kayagaki N, Wong MT, Stowe IB, Ramani SR, Gonzalez LC, Akashi-Takamura $S$, et al. Noncanonical inflammasome activation by intracellular LPS independent of TLR4. Science. 2013;341(6151):1246-9. https://doi.org/10.112 6/science.1240248.

51. Hagar JA, Powell DA, Aachoui Y, Ernst RK, Miao EA. Cytoplasmic LPS activates caspase-11: implications in TLR4-independent endotoxic shock. Science. 2013;341(6151):1250-3. https://doi.org/10.1126/science.1240988.

52. Sandanger $\varnothing$, Ranheim $T$, Vinge LE, Bliksøen $M$, Alfsnes $K$, Finsen AV, et al. The NLRP3 inflammasome is up-regulated in cardiac fibroblasts and mediates myocardial ischaemia-reperfusion injury. Cardiovasc Res. 2013; 99(1):164-74. https://doi.org/10.1093/cvr/cvt091.

53. Fann DY, Lee SY, Manzanero S, Tang SC, Gelderblom M, Chunduri P, et al. Intravenous immunoglobulin suppresses NLRP1 and NLRP3 inflammasomemediated neuronal death in ischemic stroke. Cell Death Dis. 2013;4(9):e790. https://doi.org/10.1038/cddis.2013.326.

54. Averette KM, Pratt MR, Yang Y, Bassilian S, Whitelegge JP, Loo JA, et al. Anthrax lethal toxin induced lysosomal membrane permeabilization and cytosolic cathepsin release is Nlrp1b/Nalp1b-dependent. PLoS One. 2009; 4(11):e7913. https://doi.org/10.1371/journal.pone.0007913.

55. Vladimer Gl, Weng D, Paquette SW, Vanaja SK, Rathinam VA, Aune MH, et al. The NLRP12 inflammasome recognizes Yersinia pestis. Immunity. 2012 Jul 27 37(1):96-107. https://doi.org/10.1016/j.immuni.2012.07.006.

56. Ataide MA, Andrade WA, Zamboni DS, Wang D, Souza Mdo C, Franklin BS, et al. Malaria-induced NLRP12/NLRP3-dependent caspase-1 activation mediates inflammation and hypersensitivity to bacterial superinfection. PLoS Pathog. 2014;10(1):e1003885. https://doi.org/10.1371/journal.ppat.1003885.

57. Zaki MH, Man SM, Vogel P, Lamkanfi M, Kanneganti TD. Salmonella exploits NLRP12-dependent innate immune signaling to suppress host defenses during infection. Proc Natl Acad Sci U S A. 2014;111(1):385-90. https://doi. org/10.1073/pnas.1317643111.

58. Silveira TN, Gomes MT, Oliveira LS, Campos PC, Machado GG, Oliveira SC. NLRP12 negatively regulates proinflammatory cytokine production and host defense against Brucella abortus. Eur J Immunol. 2017;47(1):51-9. https://doi. org/10.1002/eji.201646502.

59. Carswell EA, Old LJ, Kassel RL, Green S, Fiore N, Williamson B. An endotoxininduced serum factor that causes necrosis of tumors. Proc Natl Acad Sci U S A. 1975;72(9):3666-70. https://doi.org/10.1073/pnas.72.9.3666.

60. Kutukculer N, Topyildiz E, Berdeli A, Guven Bilgin B, Aykut A, Durmaz A, et al. Four diseases, PLAID, APLAID, FCAS3 and CVID and one gene (PHOSPHOLIPASE C, GAMMA-2; PLCG2): Striking clinical phenotypic overlap and difference. Clin Case Rep. 2021;9(4):2023-31. https://doi.org/10.1002/ ccr3.3934.

61. Sims R, van der Lee SJ, Naj AC, Bellenguez C, Badarinarayan N, Jakobsdottir $J$, et al. Rare coding variants in PLCG2, ABI3, and TREM2 implicate microglial-mediated innate immunity in Alzheimer's disease. Nat Genet. 2017:49:1373-84. https://doi.org/10.1038/ng.3916.

62. van der Lee SJ, Conway OJ, Jansen I, Carrasquillo MM, Kleineidam L, van

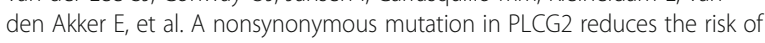
Alzheimer's disease, dementia with Lewy bodies and frontotemporal dementia, and increases the likelihood of longevity. Acta Neuropathol. 2019; 138:237-50. https://doi.org/10.1007/s00401-019-02026-8.

63. Chung LK, Park YH, Zheng Y, Brodsky IE, Hearing P, Kastner DL, et al. The Yersinia virulence factor YopM hijacks host kinases to inhibit type III effector-triggered activation of the pyrin inflammasome. Cell Host Microbe. 2016;20(3):296-306. https://doi.org/10.1016/j.chom.2016.07.018.

64. Talman AM, Chong R, Chia J, Svitkina T, Agaisse H. Actin network disassembly powers dissemination of Listeria monocytogenes. J Cell Sci. 2014;127:240-9. https://doi.org/10.1242/jcs.140038.

65. Janssen WJM, Grobarova V, Leleux J, Jongeneel L, van Gijn M, van Montfrans JM, et al. Proline-serine-threonine phosphatase interacting protein 1 (PSTPIP1) controls immune synapse stability in human T cells. J Allergy Clin Immunol. 2018;142(6):1947-55. https://doi.org/10.1016/j.jaci.201 8.01.030.

66. Yvan-Charvet L, Bonacina F, Guinamard RR, Norata GD. Immunometabolic function of cholesterol in cardiovascular disease and beyond. Cardiovasc Res. 2019;115(9):1393-407. https://doi.org/10.1093/cvr/cvz127.

67. Sutterwala FS, Mijares LA, Li L, Ogura Y, Kazmierczak BI, Flavell RA. Immune recognition of Pseudomonas aeruginosa mediated by the IPAF/NLRC4 inflammasome. J Exp Med. 2007;204(13):3235-45. https://doi.org/10.1084/ jem.20071239.

68. Canna SW, de Jesus AA, Gouni S, Brooks SR, Marrero B, Liu Y, et al. An activating NLRC4 inflammasome mutation causes autoinflammation with 
recurrent macrophage activation syndrome. Nat Genet. 2014;46(10):1140-6. https://doi.org/10.1038/ng.3089.

69. Gandotra S, Jang S, Murray PJ, Salgame P, Ehrt S. Nucleotide-binding oligomerization domain protein 2-deficient mice control infection with Mycobacterium tuberculosis. Infect Immun. 2007;75(11):5127-34. https://doi. org/10.1128/IAl.00458-07.

70. Adrianto I, Wen F, Templeton A, Wiley G, King JB, Lessard CJ, et al. Association of a functional variant downstream of TNFAIP3 with systemic lupus erythematosus. Nat Genet. 2011;43:253-8. https://doi.org/10.1038/ng.766.

71. Moaaz M, Mohannad N. Association of the polymorphisms of TRAF1 (rs10818488) and TNFAIP3 (rs2230926) with rheumatoid arthritis and systemic lupus erythematosus and their relationship to disease activity among Egyptian patients. Cent Eur J Immunol. 2016;41(2):165-75. https:// doi.org/10.5114/ceji.2016.60991.

72. Vozandychova V, Stojkova P, Hercik K, Rehulka P, Stulik J. The ubiquitination system within bacterial host-pathogen interactions. Microorganisms. 2021; 9(3):638. https://doi.org/10.3390/microorganisms9030638.

73. van Wijk SJL, Fricke F, Herhaus L, Gupta J, Hötte K, Pampaloni F, et al. Linear ubiquitination of cytosolic Salmonella Typhimurium activates NF-kB and restricts bacterial proliferation. Nat Microbiol. 2017;2(7):17066. https://doi. org/10.1038/nmicrobiol.2017.66

74. Kaneko N, Kurata M, Yamamoto T, Morikawa S, Masumoto J. The role of interleukin-1 in general pathology. Inflamm Regen. 2019;39(1):12. https://doi. org/10.1186/s41232-019-0101-5

75. Pendergraft WF 3rd, Means TK. AGS, SLE, and RNASEH2 mutations: translating insights into therapeutic advances. J Clin Invest. 2015;125(1):1024. https://doi.org/10.1172/JCI78533.

76. Kim H, Sanchez GA, Goldbach-Mansky R. Insights from Mendelian interferonopathies: comparison of CANDLE, SAVI with AGS, monogenic lupus. J Mol Med (Berl). 2016;94(10):1111-27. https://doi.org/10.1007/s00109016-1465-5.

77. Xu J, Liu H, Yang Y, Wang X, Liu P, Li Y, et al. Genome-wide profiling of cervical RNA-binding proteins identifies human papillomavirus regulation of RNASEH2A expression by viral E7 and E2F1. mBio. 2019;10:e02687-18. https://doi.org/10.1128/mBio.02687-18.

78. Saiada F, Zhang K, Li R. PIAS1 potentiates the anti-EBV activity of SAMHD1 through SUMOylation. Cell Biosci. 2021;11(1):127. https://doi.org/10.1186/s13 578-021-00636-y.

79. Martinat C, Cormier A, Tobaly-Tapiero J, Palmic N, Casartelli N, Mahboubi B, et al. SUMOylation of SAMHD1 at Lysine 595 is required for HIV-1 restriction in non-cycling cells. Nat Commun. 2021;12(1):4582. https://doi.org/10.1038/ s41467-021-24802-5.

80. Wang L, Sun Y, Song X, Wang Z, Zhang Y, Zhao Y, et al. Hepatitis B virus evades immune recognition via RNA adenosine deaminase ADAR1mediated viral RNA editing in hepatocytes. Cell Mol Immunol. 2021;18(8): 1871-82. https://doi.org/10.1038/s41423-021-00729-1.

81. Khadka S, Williams CG, Sweeney-Gibbons J, Basler CF. 3' untranslated regions of Marburg and Ebola virus mRNAs possess negative regulators of translation that are modulated by ADAR1 editing. J Virol. 2021:JVI0065221. https://doi.org/10.1128/JVI.00652-21 Online ahead of print.

82. Andrejeva J, Childs KS, Young DF, Carlos TS, Stock N, Goodbourn S, et al. The $V$ proteins of paramyxoviruses bind the IFN-inducible RNA helicase, mda-5, and inhibit its activation of the IFN-beta promoter. Proc Natl Acad Sci U S A. 2004;101(49):17264-9. https://doi.org/10.1073/pnas.0407639101.

83. Kato H, Takeuchi O, Sato S, Yoneyama M, Yamamoto M, Matsui K, et al. Reis e Sousa C, Matsuura Y, Fujita T, Akira S. Differential roles of MDA5 and RIG-I helicases in the recognition of RNA viruses. Nature. 2006;441(7089):101-5. https://doi.org/10.1038/nature04734.

84. Staels F, Betrains A, Doubel P, Willemsen M, Cleemput V, Vanderschueren S, et al. Adult-onset ANCA-associated vasculitis in SAVI: extension of the phenotypic spectrum, case report and review of the literature. Front Immunol. 2020;11:575219. https://doi.org/10.3389/fimmu.2020.575219.

85. Barber GN. STING: infection, inflammation and cancer. Nat Rev Immunol. 2015;15(12):760-70. https://doi.org/10.1038/nri3921.

86. Deng Z, Chong Z, Law CS, Mukai K, Ho FO, Martinu T, et al. A defect in COPI-mediated transport of STING causes immune dysregulation in COPA syndrome. J Exp Med. 2020;217(11):e20201045. https://doi.org/10.1084/jem.2 0201045.

87. Ichikawa HT, Conley T, Muchamuel T, Jiang J, Lee S, Owen T, et al. Beneficial effect of novel proteasome inhibitors in murine lupus via dual inhibition of type I interferon and autoantibody-secreting cells. Arthritis Rheum. 2012 64(2):493-503. https://doi.org/10.1002/art.33333.

88. Kasahara M. Role of immunoproteasomes and thymoproteasomes in health and disease. Pathol Int. 2021;71(6):371-82. https://doi.org/10.1111/pin.13088

89. Hutchinson S, Sims S, O'Hara G, Silk J, Gileadi U, Cerundolo V, et al. A dominant role for the immunoproteasome in CD8+ T cell responses to murine cytomegalovirus. PLoS One. 2011;6(2):e14646. https://doi.org/10.13 71/journal.pone.0014646.

90. Robek MD, Garcia ML, Boyd BS, Chisari FV. Role of immunoproteasome catalytic subunits in the immune response to hepatitis B virus. J Virol. 2007; 81(2):483-91. https://doi.org/10.1128/JVI.01779-06.

91. Van Kaer L, Ashton-Rickardt PG, Eichelberger M, Gaczynska M, Nagashima K, Rock KL, et al. Altered peptidase and viral-specific T cell response in LMP2 mutant mice. Immunity. 1994;1(7):533-41. https://doi.org/10.1016/1074-7613 (94)90043-4.

92. Zieba BA, Henry L, Lacroix M, Jemaà M, Lavabre-Bertrand $T$, Meunier L, et al. The proteasome maturation protein POMP increases proteasome assembly and activity in psoriatic lesional skin. J Dermatol Sci. 2017;88(1):10-9. https:// doi.org/10.1016/j.jdermsci.2017.04.009.

93. Boner W, Morgan IM. Novel cellular interacting partners of the human papillomavirus 16 transcription/replication factor E2. Virus Res. 2002;90(1-2): 113-8. https://doi.org/10.1016/s0168-1702(02)00145-4.

94. Oliveira L, Sinicato NA, Postal M, Appenzeller S, Niewold TB. Dysregulation of antiviral helicase pathways in systemic lupus erythematosus. Front Genet. 2014;5:418. https://doi.org/10.3389/fgene.2014.00418.

95. Kato H, Fujita T. RIG-l-like receptors and autoimmune diseases. Curr Opin Immunol. 2015;37:40-5. https://doi.org/10.1016/j.coi.2015.10.002.

96. Masters SL, Gerlic M, Metcalf D, Preston S, Pellegrini M, O'Donnell JA, et al. NLRP1 inflammasome activation induces pyroptosis of hematopoietic progenitor cells. Immunity. 2012;37(6):1009-23. https://doi.org/10.1016/j. immuni.2012.08.027.

97. Grandemange S, Sanchez E, Louis-Plence P, Tran Mau-Them F, Bessis D, Coubes $C$, et al. A new autoinflammatory and autoimmune syndrome associated with NLRP1 mutations: NAIAD (NLRP1-associated autoinflammation with arthritis and dyskeratosis). Ann Rheum Dis. 2017; 76(7):1191-8. https://doi.org/10.1136/annrheumdis-2016-210021.

98. Soler VJ, Tran-Viet KN, Galiacy SD, Limviphuvadh V, Klemm TP, St Germain E, et al. Whole exome sequencing identifies a mutation for a novel form of corneal intraepithelial dyskeratosis. J Med Genet. 2013;50(4):246-54. https:// doi.org/10.1136/jmedgenet-2012-101325.

99. Herlin T, Jørgensen SE, Høst C, Mitchell PS, Christensen MH, Laustsen M, et al. Autoinflammatory disease with corneal and mucosal dyskeratosis caused by a novel NLRP1 variant. Rheumatology (Oxford). 2020;59:2334-9. https://doi.org/10.1093/rheumatology/kez612.

100. Sandstrom A, Mitchell PS, Goers L, Mu EW, Lesser CF, Vance RE. Functional degradation: a mechanism of NLRP1 inflammasome activation by diverse pathogen enzymes. Science. 2019;364:eaau1330. https://doi.org/10.1126/ science.aau1330.

101. Jéru I, Duquesnoy P, Fernandes-Alnemri T, Cochet E, Yu JW, Lackmy-Port-Lis $M$, et al. Mutations in NALP12 cause hereditary periodic fever syndromes. Proc Natl Acad Sci U S A. 2008;105(5):1614-9. https://doi.org/10.1073/pnas. 0708616105.

102. Del Porto F, Cifani N, Proietta M, Verrecchia E, Di Rosa R, Manna R, et al. NLRP12 gene mutations and auto-inflammatory diseases: ever-changing evidence. Rheumatology (Oxford). 2020;59(11):3129-36. https://doi.org/10.1 093/rheumatology/keaa304.

103. Lachmann HJ, Papa R, Gerhold K, Obici L, Touitou I, Cantarini L, et al. Paediatric Rheumatology International Trials Organisation (PRINTO), the EUROTRAPS and the Eurofever Project. The phenotype of TNF receptorassociated autoinflammatory syndrome (TRAPS) at presentation: a series of 158 cases from the Eurofever/EUROTRAPS international registry. Ann Rheum Dis. 2014;73:2160-7. https://doi.org/10.1136/annrheumdis-2013-204184.

104. Bulua AC, Simon A, Maddipati R, Pelletier M, Park H, Kim KY, et al. Mitochondrial reactive oxygen species promote production of proinflammatory cytokines and are elevated in TNFR1-associated periodic syndrome (TRAPS). J Exp Med. 2011;208(3):519-33. https://doi.org/10.1084/ jem.20102049.

105. Simon A, Park H, Maddipati R, Lobito AA, Bulua AC, Jackson AJ, et al. Concerted action of wild-type and mutant TNF receptors enhances inflammation in TNF receptor 1-associated periodic fever syndrome. Proc 
Natl Acad Sci U S A. 2010;107(21):9801-6. https://doi.org/10.1073/pnas 0914118107.

106. Zhou Q, Lee GS, Brady J, Datta S, Katan M, Sheikh A, et al. A hypermorphic missense mutation in PLCG2, encoding phospholipase CY2, causes a dominantly inherited autoinflammatory disease with immunodeficiency. Am J Hum Genet. 2012;91(4):713-20. https://doi.org/10.1016/.j.jhg.2012.08.006.

107. Chae JJ, Park YH, Park C, Hwang IY, Hoffmann P, Kehrl JH, et al. Connecting two pathways through $\mathrm{Ca} 2+$ signaling: NLRP3 inflammasome activation induced by a hypermorphic PLCG2 mutation. Arthritis Rheum. 2015;67(2): 563-7. https://doi.org/10.1002/art.38961.

108. Lee GS, Subramanian N, Kim Al, Aksentijevich I, Goldbach-Mansky R, Sacks $D B$, et al. The calcium-sensing receptor regulates the NLRP3 inflammasome through Ca2+ and cAMP. Nature. 2012;492(7427):123-7. https://doi.org/10.1 038/nature11588.

109. The International FMF Consortium. Ancient missense mutations in a new member of the RoRet gene family are likely to cause familial Mediterranean fever. Cell. 1997;90(4):797-807. https://doi.org/10.1016/s0092-8674(00)80539-5.

110. French FMF Consortium. A candidate gene for familial Mediterranean fever. Nat Genet. 1997;17(1):25-31. https://doi.org/10.1038/ng0997-25.

111. Xu H, Yang J, Gao W, Li L, Li P, Zhang L, et al. Innate immune sensing of bacterial modifications of Rho GTPases by the Pyrin inflammasome. Nature. 2014;513(7517):237-41. https://doi.org/10.1038/nature13449.

112. Park YH, Wood G, Kastner DL, Chae JJ. Pyrin inflammasome activation and RhoA signaling in the autoinflammatory diseases FMF and HIDS. Nat Immunol. 2016;17(8):914-21. https://doi.org/10.1038/ni.3457.

113. Park YH, Remmers EF, Lee W, Ombrello AK, Chung LK, Shilei Z, et al. Ancient familial Mediterranean fever mutations in human pyrin and resistance to Yersinia pestis. Nat Immunol. 2020;21(8):857-67. https://doi.org/10.1038/s41 590-020-0705-6.

114. Chae JJ, Cho YH, Lee GS, Cheng J, Liu PP, Feigenbaum L, et al. Gain-offunction Pyrin mutations induce NLRP3 protein-independent interleukin-1 $\beta$ activation and severe autoinflammation in mice. Immunity. 2011:34(5):75568. https://doi.org/10.1016/j.immuni.2011.02.020.

115. Kile BT, Panopoulos AD, Stirzaker RA, Hacking DF, Tahtamouni LH, Willson TA, et al. Mutations in the cofilin partner Aip1/Wdr1 cause autoinflammatory disease and macrothrombocytopenia. Blood. 2007;1 10(7): 2371-80. https://doi.org/10.1182/blood-2006-10-055087.

116. Kim ML, Chae JJ, Park YH, De Nardo D, Stirzaker RA, Ko HJ, et al. Aberrant actin depolymerization triggers the pyrin inflammasome and autoinflammatory disease that is dependent on IL-18, not IL-1 $\beta$. J Exp Med. 2015;212(6):927-38. https://doi.org/10.1084/jem.20142384.

117. Rodal AA, Tetreault JW, Lappalainen P, Drubin DG, Amberg DC. Aip1p interacts with cofilin to disassemble actin filaments. J Cell Biol. 1999;145(6): 1251-64. https://doi.org/10.1083/jcb.145.6.1251.

118. Okada K, Obinata T, Abe H. XAIP1: a Xenopus homologue of yeast actin interacting protein 1 (AIP1), which induces disassembly of actin filaments cooperatively with ADF/cofilin family proteins. J Cell Sci. 1999;112(Pt 10): 1553-65. https://doi.org/10.1242/jcs.112.10.1553.

119. Standing AS, Malinova D, Hong Y, Record J, Moulding D, Blundell MP, et al. Autoinflammatory periodic fever, immunodeficiency, and thrombocytopenia (PFIT) caused by mutation in actin-regulatory gene WDR1. J Exp Med. 2017; 214(1):59-71. https://doi.org/10.1084/jem.20161228.

120. Jéru I, Papin S, L'hoste S, Duquesnoy P, Cazeneuve C, Camonis J, et al. Interaction of pyrin with 14.3 .3 in an isoform-specific and phosphorylationdependent manner regulates its translocation to the nucleus. Arthritis Rheum. 2005;52(6):1848-57. https://doi.org/10.1002/art.21050.

121. Masters SL, Lagou V, Jéru I, Baker PJ, Van Eyck L, Parry DA, et al. Familial autoinflammation with neutrophilic dermatosis reveals a regulatory mechanism of pyrin activation. Sci Transl Med. 2016;8:332ra45. https://doi. org/10.1126/scitransImed.aaf1471.

122. Moghaddas F, Llamas R, De Nardo D, Martinez-Banaclocha H, MartinezGarcia JJ, Mesa-Del-Castillo P, et al. A novel pyrin-associated autoinflammation with neutrophilic dermatosis mutation further defines 143-3 binding of pyrin and distinction to familial Mediterranean fever. Ann Rheum Dis. 2017;76(12):2085-94. https://doi.org/10.1136/annrheumdis-201 7-211473.

123. Schnappauf O, Chae JJ, Kastner DL, Aksentijevich I. The pyrin inflammasome in health and disease. Front Immunol. 2019;10:1745. https://doi.org/10.3389/ fimmu.2019.01745.

124. Wise CA, Gillum JD, Seidman CE, Lindor NM, Veile R, Bashiardes S, et al. Mutations in CD2BP1 disrupt binding to PTP PEST and are responsible for
PAPA syndrome, an autoinflammatory disorder. Hum Mol Genet. 2002;1 1(8): 961-9. https://doi.org/10.1093/hmg/11.8.961.

125. Shoham NG, Centola M, Mansfield E, Hull KM, Wood G, Wise CA, et al. Pyrin binds the PSTPIP1/CD2BP1 protein, defining familial Mediterranean fever and PAPA syndrome as disorders in the same pathway. Proc Natl Acad Sci U S A. 2003;100(23):13501-6. https://doi.org/10.1073/pnas.2135380100.

126. Drenth JP, Cuisset L, Grateau G, Vasseur C, van de Velde-Visser SD, de Jong $\mathrm{JG}$, et al. Mutations in the gene encoding mevalonate kinase cause hyperIgD and periodic fever syndrome. International Hyper-lgD Study Group. Nat Genet. 1999;22(2):178-81. https://doi.org/10.1038/9696.

127. Mandey SH, Kuijk LM, Frenkel J, Waterham HR. A role for geranylgeranylation in interleukin-1 $\beta$ secretion. Arthritis Rheum. 2006;54(11): 3690-5. https://doi.org/10.1002/art.22194.

128. Normand S, Massonnet B, Delwail A, Favot L, Cuisset L, Grateau G, et al. Specific increase in caspase-1 activity and secretion of IL-1 family cytokines: a putative link between mevalonate kinase deficiency and inflammation. Eur Cytokine Netw. 2009;20(3):101-7. https://doi.org/10.1684/ecn.2009.0163.

129. De Benedetti F, Gattorno M, Anton J, Ben-Chetrit E, Frenkel J, Hoffman HM, et al. Canakinumab for the Treatment of autoinflammatory recurrent fever syndromes. N Engl J Med. 2018;378(20):1908-19. https://doi.org/10.1056/ NEJMoa1706314.

130. Romberg N, Al Moussawi K, Nelson-Williams C, Stiegler AL, Loring E, Choi M, et al. Mutation of NLRC4 causes a syndrome of enterocolitis and autoinflammation. Nat Genet. 2014;46(10):1135-9. https://doi.org/10.1038/ ng.3066.

131. Kitamura A, Sasaki Y, Abe T, Kano H, Yasutomo K. An inherited mutation in NLRC4 causes autoinflammation in human and mice. J Exp Med. 2014; 211(12):2385-96. https://doi.org/10.1084/jem.20141091.

132. Sasaki Y, Otsuka K, Arimochi H, Tsukumo SI, Yasutomo K. Distinct roles of IL$1 \beta$ and IL-18 in NLRC4-induced autoinflammation. Front Immunol. 2020;11: 591713. https://doi.org/10.3389/fimmu.2020.591713.

133. Miceli-Richard C, Lesage S, Rybojad M, Prieur AM, Manouvrier-Hanu S, Häfner R, et al. CARD15 mutations in Blau syndrome. Nat Genet. 2001;29(1): 19-20. https://doi.org/10.1038/ng720.

134. Tanabe T, Chamaillard M, Ogura Y, Zhu L, Qiu S, Masumoto J, et al. Regulatory regions and critical residues of NOD2 involved in muramyl dipeptide recognition. EMBO J. 2004;23(7):1587-97. https://doi.org/10.1038/ sj.emboj.7600175.

135. Kanazawa N, Okafuji I, Kambe N, Nishikomori R, Nakata-Hizume M, Nagai S, et al. Early-onset sarcoidosis and CARD15 mutations with constitutive nuclear factor-KB activation: common genetic etiology with Blau syndrome. Blood. 2005;105(3):1195-7. https://doi.org/10.1182/blood-2004-07-2972.

136. Zhou Q, Wang H, Schwartz DM, Stoffels M, Park YH, Zhang Y, et al. Loss-offunction mutations in TNFAIP3 leading to A20 haploinsufficiency cause an early-onset autoinflammatory disease. Nat Genet. 2016:48:67-73. https://doi. org/10.1038/ng.3459.

137. Shigemura T, Kaneko N, Kobayashi N, Kobayashi K, Takeuchi Y, Nakano N, et al. Novel heterozygous C243Y A20/TNFAIP3 gene mutation is responsible for chronic inflammation in autosomal-dominant Behçet's disease. RMD Open. 2016;2(1):e000223. https://doi.org/10.1136/rmdopen-2015-000223.

138. Duong BH, Onizawa M, Oses-Prieto JA, Advincula R, Burlingame A, Malynn $B A$, et al. A20 restricts ubiquitination of pro-interleukin-1 $\beta$ protein complexes and suppresses NLRP3 inflammasome activity. Immunity. 2015; 42(1):55-67. https://doi.org/10.1016/j.immuni.2014.12.031.

139. Das T, Chen Z, Hendriks RW, Kool M. A20/tumor necrosis factor a-induced protein 3 in immune cells controls development of autoinflammation and autoimmunity: lessons from mouse models. Front Immunol. 2018;9:104. https://doi.org/10.3389/fimmu.2018.00104

140. Tokunaga F, Sakata S, Saeki Y, Satomi Y, Kirisako T, Kamei K, et al. Involvement of linear polyubiquitylation of NEMO in NF-KB activation. Nat Cell Biol. 2009;11(2):123-32. https://doi.org/10.1038/ncb1821.

141. Iwai K, Tokunaga F. Linear polyubiquitination: a new regulator of NF-kappaB activation. EMBO Rep. 2009;10(7):706-13. https:/doi.org/10.1038/embor.2 009.144.

142. Kirisako T, Kamei K, Murata S, Kato M, Fukumoto H, Kanie M, et al. A ubiquitin ligase complex assembles linear polyubiquitin chains. EMBO J. 2006;25(20):4877-87. https://doi.org/10.1038/sj.emboj.7601360.

143. Ikeda F, Deribe YL, Skånland SS, Stieglitz B, Grabbe C, Franz-Wachtel M, et al. SHARPIN forms a linear ubiquitin ligase complex regulating NF-KB activity and apoptosis. Nature. 2011;471(7340):637-41. https://doi.org/10.1038/na ture09814. 
144. Gerlach B, Cordier SM, Schmukle AC, Emmerich CH, Rieser E, Haas TL, et al. Linear ubiquitination prevents inflammation and regulates immune signalling. Nature. 2011;471(7340):591-6. https://doi.org/10.1038/nature09816.

145. Tokunaga F, Nakagawa T, Nakahara M, Saeki Y, Taniguchi M, Sakata S, et al. SHARPIN is a component of the NF-KB-activating linear ubiquitin chain assembly complex. Nature. 2011;471(7340):633-6. https://doi.org/10.1038/na ture09815.

146. Boisson B, Laplantine E, Prando C, Giliani S, Israelsson E, Xu Z, et al. Immunodeficiency, autoinflammation and amylopectinosis in humans with inherited HOIL-1 and LUBAC deficiency. Nat Immunol. 2012;13:1178-86. https://doi.org/10.1038/ni.2457.

147. Schaeffer V, Akutsu M, Olma MH, Gomes LC, Kawasaki M, Dikic I. Binding of OTULIN to the PUB domain of HOIP controls NF-KB signaling. Mol Cell. 2014;54(3):349-61. https://doi.org/10.1016/j.molcel.2014.03.016.

148. Boisson B, Laplantine E, Dobbs K, Cobat A, Tarantino N, Hazen M, et al Human HOIP and LUBAC deficiency underlies autoinflammation, immunodeficiency, amylopectinosis, and lymphangiectasia. J Exp Med. 212: 939-51. https://doi.org/10.1084/jem.20141130.

149. Damgaard RB, Walker JA, Marco-Casanova P, Morgan NV, Titheradge HL, Elliott PR, et al. The Deubiquitinase OTULIN is an essential negative regulator of inflammation and autoimmunity. Cell. 2016;166:1215-1230.e20. https://doi.org/10.1016/j.cell.2016.07.019.

150. Zhou Q, Yu X, Demirkaya E, Deuitch N, Stone D, Tsai WL, et al. Biallelic hypomorphic mutations in a linear deubiquitinase define otulipenia, an early-onset autoinflammatory disease. Proc Natl Acad Sci U S A. 2016; 113(36):10127-32. https://doi.org/10.1073/pnas.1612594113.

151. Damgaard RB, Elliott PR, Swatek KN, Maher ER, Stepensky P, Elpeleg O, et al. OTULIN deficiency in ORAS causes cell type-specific LUBAC degradation, dysregulated TNF signalling and cell death. EMBO Mol Med. 2019;11:e9324. https://doi.org/10.15252/emmm.201809324.

152. Chen D, Li Z, Liu Y, Sampaio N, Yang D, Aksentijevich I, et al. Human induced pluripotent stem cells generated from a patient with a homozygous L272P mutation in the OTULIN gene (NIHTVBi014-A). Stem Cell Res. 2020;47:101921. https://doi.org/10.1016/j.scr.2020.101921.

153. Aksentijevich I, Masters SL, Ferguson PJ, Dancey P, Frenkel J, van RoyenKerkhoff $A$, et al. An autoinflammatory disease with deficiency of the interleukin-1-receptor antagonist. N Engl J Med. 2009;360:2426-37. https:// doi.org/10.1056/NEJMoa0807865.

154. Reddy S, Jia S, Geoffrey R, Lorier R, Suchi M, Broeckel U, et al. An autoinflammatory disease due to homozygous deletion of the IL 1RN locus. N Engl J Med. 2009;360(23):2438-44. https://doi.org/10.1056/NEJMoa 0809568.

155. Jesus AA, Osman M, Silva CA, Kim PW, Pham TH, Gadina M, et al. A novel mutation of ILIRN in the deficiency of interleukin-1 receptor antagonist syndrome: description of two unrelated cases from Brazil. Arthritis Rheum. 2011;63(12):4007-17. https://doi.org/10.1002/art.30588.

156. Jesus AA, Goldbach-Mansky R. IL-1 blockade in autoinflammatory syndromes. Annu Rev Med. 2014;65(1):223-44. https://doi.org/10.1146/a nnurev-med-061512-150641.

157. Rodero MP, Crow YJ. Type I interferon-mediated monogenic autoinflammation: The type I interferonopathies, a conceptual overview. J Exp Med. 2016;213(12):2527-38. https://doi.org/10.1084/jem.20161596.

158. Crow YJ, Rehwinkel J. Aicardi-Goutières syndrome and related phenotypes: linking nucleic acid metabolism with autoimmunity. Hum Mol Genet. 2009; 18(R2):R130-6. https://doi.org/10.1093/hmg/ddp293.

159. Crow YJ, Chase DS, Lowenstein Schmidt J, Szynkiewicz M, Forte GM, Gornall $\mathrm{HL}$, et al. Characterization of human disease phenotypes associated with mutations in TREX1, RNASEH2A, RNASEH2B, RNASEH2C, SAMHD1, ADAR, and IFIH1. Am J Med Genet A. 2015;167A:296-312. https://doi.org/10.1002/a jmg.a.36887.

160. Liu Y, Jesus AA, Marrero B, Yang D, Ramsey SE, GAM S, et al. Activated STING in a vascular and pulmonary syndrome. N Engl J Med. 2014;371:50718. https://doi.org/10.1056/NEJMoa1312625.

161. Watkin LB, Jessen B, Wiszniewski W, Vece TJ, Jan M, Sha $Y$, et al. COPA mutations impair ER-Golgi transport and cause hereditary autoimmunemediated lung disease and arthritis. Nat Genet. 2015;47:654-60. https://doi. org/10.1038/ng.3279.

162. Arima K, Kinoshita A, Mishima H, Kanazawa N, Kaneko T, Mizushima T, et al. Proteasome assembly defect due to a proteasome subunit beta type 8 (PSMB8) mutation causes the autoinflammatory disorder, Nakajo-Nishimura syndrome. Proc Natl Acad Sci U S A. 2011;108:14914-9. https://doi.org/10.1 073/pnas.1106015108

163. Brehm A, Liu Y, Sheikh A, Marrero B, Omoyinmi E, Zhou Q, et al. Additive loss-of-function proteasome subunit mutations in CANDLE/PRAAS patients promote type I IFN production. J Clin Invest. 2015;125:4196-211. https://doi. org/10.1172/JCl81260

164. Feigenbaum A, Müller C, Yale C, Kleinheinz J, Jezewski P, Kehl HG, et al. Singleton-Merten syndrome: an autosomal dominant disorder with variable expression. Am J Med Genet A. 2013;161A(2):360-70. https://doi.org/10.1 002/ajmg.a.35732.

165. Jang MA, Kim EK, Now H, Nguyen NT, Kim WJ, Yoo JY, et al. Mutations in DDX58, which encodes RIG-I, cause atypical Singleton-Merten syndrome. Am J Hum Genet. 2015;96(2):266-74. https://doi.org/10.1016/j.ajhg.2014.11.019.

\section{Publisher's Note}

Springer Nature remains neutral with regard to jurisdictional claims in published maps and institutional affiliations.
Ready to submit your research? Choose BMC and benefit from:

- fast, convenient online submission

- thorough peer review by experienced researchers in your field

- rapid publication on acceptance

- support for research data, including large and complex data types

- gold Open Access which fosters wider collaboration and increased citations

- maximum visibility for your research: over $100 \mathrm{M}$ website views per year

At $\mathrm{BMC}$, research is always in progress.

Learn more biomedcentral.com/submissions 